University of San Diego

Digital USD

Theses

Theses and Dissertations

Winter 1-2018

\title{
Copepod distribution in relation to environmental parameters on diel and tidal time scales in Mission Bay, San Diego, California
}

Joy Renee Shapiro

University of San Diego

Follow this and additional works at: https://digital.sandiego.edu/theses

Part of the Laboratory and Basic Science Research Commons, and the Marine Biology Commons

\section{Digital USD Citation}

Shapiro, Joy Renee, "Copepod distribution in relation to environmental parameters on diel and tidal time scales in Mission Bay, San Diego, California" (2018). Theses. 26.

https://digital.sandiego.edu/theses/26

This Thesis: Open Access is brought to you for free and open access by the Theses and Dissertations at Digital USD. It has been accepted for inclusion in Theses by an authorized administrator of Digital USD. For more information, please contact digital@sandiego.edu. 


\title{
UNIVERSITY OF SAN DIEGO
}

\author{
San Diego
}

\section{Copepod distribution in relation to environmental parameters on diel and tidal time scales in Mission Bay, San Diego, California}

A thesis submitted in partial satisfaction of the requirements for the degree of

Master of Science in Marine Science

by

Joy Renee Shapiro

Thesis Committee

Ronald S. Kaufmann, Ph.D., Chair Jennifer C. Prairie, Ph.D.

Nathalie B. Reyns, Ph.D. 
The thesis of Joy Renee Shapiro is approved by:

Ronald S. Kaufmann, Thesis Committee Chair University of San Diego

Jennifer C. Prairie, Thesis Committee Member University of San Diego

Nathalie Reyns, Thesis Committee Member

University of San Diego

University of San Diego

San Diego

2018 
Copyright 2018 Joy Renee Shapiro 


\section{ACKNOWLEDGMENTS}

I would first like to thank my wonderful family whom, without their immense support and love, this would not be possible. Thank you, Ron and Ellen for always being my cheering squad, rock, and inspiration. I would like to give a special thank you to my sisters, Kelly Abma, Katie Trott, and Thaïs Fournier for always being by my side, making me laugh, giving me the courage and strength to persist, and for sending me never-ending encouragement and support.

Additionally, I would also like to thank my companies Ocean Lab and Apium for their financial and emotional support. Without the generosity, compassion, and support of my boss, Tyler MacCready, I would not have had this amazing opportunity. Thanks to my committee chair, Ron Kaufmann for the countless hours of council and encouragement for my research. I appreciate all of the advice, feedback, and support over the many years. I would also like to give many thanks to the rest of my committee, Jennifer Prairie and Nathalie Reyns for their help and support in structuring my research and understanding my results. Thank you for always making sure my research was on the right track. Lastly, I would like to thank the amazing undergraduate and graduate students that helped me complete my research. I would specifically like to thank Garrett Evensen, Cristina Clark, Kate Hargenrader, Kaitlin Lathrop, and Laura Schwebel for bending over backwards to help me complete my research. You all are truly amazing and I can't thank you enough. 


\section{DEDICATION}

This thesis is dedicated to the brilliant Melvin Sykes, the loving Dr.

Thomas J. Surdacki, the beautiful and courageous Edwina Surdacki, the vivacious Jean Bachley, and the honorable Eleanor Surdacki. These five honorable souls are the reason I have accomplished so much in my life. Thank you for giving me so much to look up to, aspire to, and for inspiring me daily. Each of you was a pioneer in your own right, and I am honored to have had you in my life. 
TABLE OF CONTENTS

List of Figures ………............................................................................

List of Tables ...........................................................................................

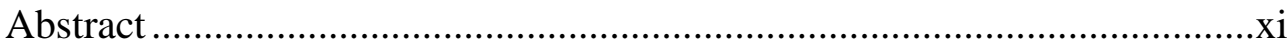

I. CHAPTER 1: GENERAL THESIS INTRODUCTION.......................

1.1 Spatial and Temporal Variability of Copepods ...........................1

1.2 Mission Bay, San Diego ..............................................................

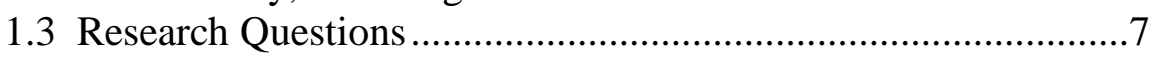

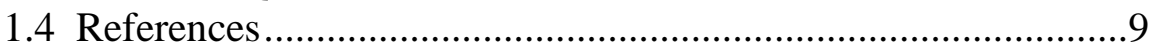

II. CHAPTER 2: COPEPOD DISTRIBUTION IN RELATION TO ENVIRONMENTAL PARAMETERS ON DIEL AND TIDAL TIME SCALES IN MISSION BAY, SAN DIEGO, CALIFRONIA.....................................12

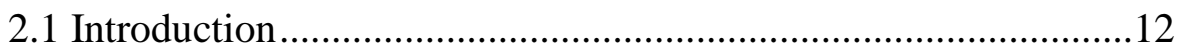

2.1.1 Spatial and Temporal Variability of Copepods....................12

2.2 Materials and Methods..............................................................16

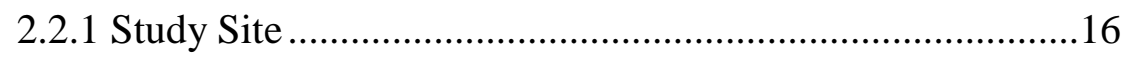

2.2.2 Field Methods ……………….........................................19

2.2.3 Lab Methods .....................................................................22

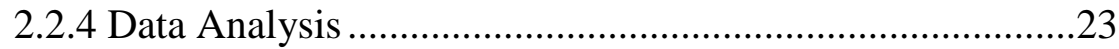

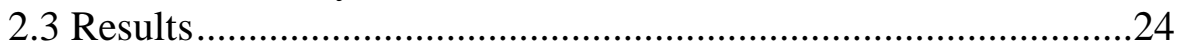

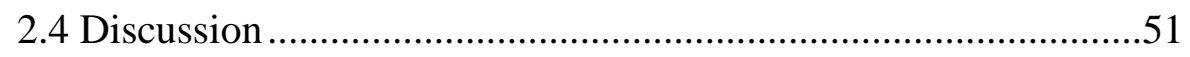

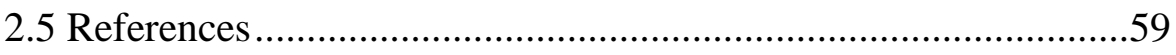

III. CHAPTER 3: GENERAL THESIS CONCLUSION ................................65

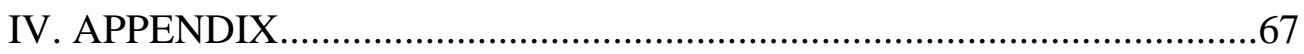




\section{LIST OF FIGURES}

Figure 1. Map of Mission Bay, San Diego, California ...............................18

Figure 2. Surface and bottom copepod adult, juvenile and

nauplii densities over time .28

Figure 3. Surface copepod adult, juvenile and nauplii densities

vs. hydrographic parameters 


\section{LIST OF TABLES}

Table 1. Date and location of sampling...............................................21

Table 2. Five most numerically dominant taxa ......................................26

Table 3. Mean Shannon-Wiener, evenness, and species richness

for each site and month

Table 4. Kruskal-Wallis ANOVA for copepod adult, juvenile and nauplii densities,

diversity, evenness and richness in four time of day/tidal phase categories: day/flood, day/ebb, night/flood, night/ebb.

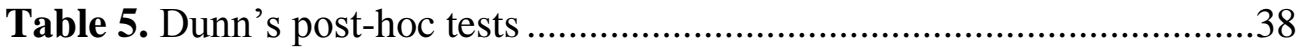

Table 6. Pearson's correlations between adults and juveniles, nauplii, and tidal height

Table 7. Pearson's correlations between temperature, salinity, pigments, copepods, and nauplii 


\begin{abstract}
The vertical distribution of copepods in estuaries is known to vary in relation to environmental factors. However, the relationships between environmental conditions (e.g., tides, hydrography) and copepod distributions are not well understood. This project examined connections between environmental parameters and copepod distribution in Mission Bay, San Diego, California. Copepods (adults, juveniles, and nauplii) were collected every two hours over a diel cycle at three sites across the bay. A plankton pump was used to draw $\sim 2 \mathrm{~m}^{3}$ of water from each of two depths - just below the surface and just above the bottom. Copepods were retained in a $100 \mu \mathrm{m}$ mesh net, enumerated and identified to the lowest possible taxon. Results showed that the vertical distribution of copepods only varied over time at the front bay site, perhaps due to vertical migration on diel and tidal time scales. At this site, densities were highest in the bottom of the water column during night ebb tides and lowest in the surface and near-bottom samples during day flood tides. This result suggests that copepods were migrating between the near-bottom waters and the middle of the water column throughout the day. A strong oceanic influence was apparent in both hydrographic parameters and migration patterns in the front bay. Samples from the front bay site contained mostly coastal species, whereas samples from the mid bay site contained both estuarine and coastal species, while mostly estuarine species were identified from the back bay site. The results provide support that tides have a strong influence on copepod density in the front portion of Mission Bay and that both active and passive migration behaviors can be present within a
\end{abstract}


species, depending on hydrographic conditions in a particular region of Mission Bay. 


\section{CHAPTER 1: GENERAL THESIS INTRODUCTION}

\section{INTRODUCTION}

\subsection{SPATIAL AND TEMPORAL VARIABILITY OF COPEPODS}

Copepods are key components of marine ecosystems and play important functional roles in estuarine ecosystem dynamics (e.g., Kleppel 1993, Day et al. 2013). The species of copepods present in an estuary can reflect hydrographic conditions. For example, in the St. Lawrence Estuary, copepod concentrations were highest in the least stratified portions of the estuary (Laprise and Dodson 1994). In addition, in the Bilbao Estuary (Spain), larger copepods were more sensitive to changes in water quality, such as dissolved oxygen and turbidity, whereas smaller copepods were affected more by phytoplankton biomass and temperature (Intxausti et al. 2012). These relationships were determined by correlating factors such as chlorophyll $a$, temperature, salinity, dissolved oxygen, and Secchi disk depth with copepod abundance. Densities of copepods smaller than $200 \mu \mathrm{m}$ were strongly positively correlated with Secchi disk depth and dissolved oxygen, whereas densities of copepods smaller than $100 \mu \mathrm{m}$ were strongly positively correlated with chlorophyll $a$ and temperature. This phenomenon could be in part due to the foraging habits of each size class. Smaller copepods feed on phytoplankton, represented by chlorophyll $a$, while larger copepods feed on both phytoplankton and smaller zooplankton. Turbidity can also affect copepod abundance (Morgan et al. 1997). In the Columbia River estuary, Coullana canadensis was more abundant in areas of high turbidity. Another 
example of hydrographic parameters affecting copepod composition can be found in the Jiulong Estuary in China. At the mouth of the estuary where salinity was highest, Calanus sinicus was most abundant. However, as salinity decreased farther into the estuary, $C$. sinicus became less abundant, and more estuarine species of copepods with tolerance for lower salinity, such as Tortanus derjugini and Acartia sinesis, were present (Xu et al. 2007). The effects of salinity on species composition have also been observed in Mission Bay, San Diego, California. When there were large inputs of fresh water that decreased salinity and increased nutrients within Mission Bay, more copepod species were present. However, when the estuary was inversely stratified, more tintinnid species were abundant and relatively few copepods were observed (Elliott and Kaufmann 2007).

Copepod patchiness also can be related to food availability. It is well known that many copepods feed on phytoplankton (Landry and Hassett 1982, Landry et al. 1998, Stoecker and Capuzzo 1990, Strom et al. 2001). Strong correlations have been observed between micro-zooplankton biomass and chlorophyll concentrations (Strom et al. 2001), and copepod grazing removes much of the phytoplankton production in parts of the North Pacific. Additionally, micro-zooplankton grazing can consume up to $24 \%$ of the phytoplankton biomass (Landry and Hassett 1982). However, lack of phytoplankton can also dictate copepod composition and abundance. Toward the end of the summer in Mission Bay (a Mediterranean-climate estuary), when bloom conditions were still 
favorable but food was scarce, smaller copepods tended to prevail and were found where phytoplankton abundance was higher (Elliott and Kaufmann 2007).

Tides are also very important in contributing to copepod patchiness in bays and estuaries. In Westernport Bay (Australia), vertical position in the water column of Acartia tranteri, was significantly affected by tides, and copepod movement in relation to the tides aided their retention in the bay (Kimmerer and McKinnon 1987). Kimmerer et al. (2014) modeled zooplankton behavior and found that particles exhibiting realistic copepod migratory behavior were shallower in the water column during flood tides and deeper during ebb tides. This behavior led to retention of migratory particles within the estuary. By contrast, most of the passive particles in their model did not remain in the estuary and were transported seaward. While copepod patchiness was observed, this pattern may have resulted from interactions between the particles' vertical movements and the bathymetry of the estuary. Similar results were observed in the Conwy Estuary (North Wales), in which copepod abundance was greatest in the seaward portion of the estuary during flood tide and lowest in the landward portion of the estuary during ebb tide (Hough and Naylor 1991). In addition, the copepod, Eurytemora affinis, was observed in greater abundance at shallower depths during spring tides and deeper in the water column during neap tides. This result led Hough and Naylor (1991) to determine that E. affinis was actively swimming to maintain its position in the water column during semi-lunar cycles. Similar results were observed in the Mantang Estuary (China). where more estuarine copepods were abundant shallow in the water column during the night 
time flood tide while more marine copepods were present deep in the water column during the night time ebb tide (Chew et al. 2015). It was inferred that the estuarine copepod species were migrating so as to be retained in the estuary, and that the marine species were acting so as to be advected from the estuary. The tidal migration behavior of copepods for estuarine retention has also been observed in the Jiulong Estuary in China (Xu et al. 2007), the Columbia River estuary in the United States (Morgan et al. 1997), and the Sundays River estuary in South Africa (Wooldridge and Erasmus 1980).

Vertical migration by copepods in estuaries can also be affected by predation. Tidal migration for retention was prominent during day tides in the Chikugo River Estuary, Japan (Ueda et al. 2010). However, at night the calanoid copepod Pseudodiaptomus inopinus migrated in a manner related more closely to predator avoidance than estuarine retention. In the Cochin Backwaters Estuary (India), tides had less effect on Decapoda (Luciferidae), Mysidacea, and Amphipoda than diel vertical migration for predator avoidance (Vineetha et al. 2015).

In Mission Bay, copepod distributions across regions of the bay have been characterized over multiple annual cycles. Elliott and Kaufmann (2007) found that zooplankton in the back bay were predominantly estuarine species and primarily holoplankton, with increasing densities of neritic species and larval forms of benthic species in the mid and front bay. The front bay species assemblage, in particular, often was dominated by larvae and neritic copepods 
(Elliott and Kaufmann 2007). These results suggest decreasing exchange with the coastal ocean in relation to distance from the mouth and that zooplankton behavior might differ in different regions of the bay to enhance retention, in relation to a particular lifestyle. Prior to this study, vertical distributions of copepods within broad regions of Mission Bay and in relation to environmental parameters, including tidal phase, had not been examined.

Copepod abundance and species composition also exhibit temporal variation on a variety of time scales. Research in the mesotidal Mondego River estuary (Portugal) found that vertical distributions of copepods were related primarily to water depth and tidal currents, though day-night patterns were important during the summer (Gonçalves et al. 2012). Most of the copepod species examined in the study had high densities during spring tides in winter, but were more abundant during neap tides throughout the rest of the year. Early life stages of these copepods were most abundant near the bottom of the estuary during ebb tides, which should enhance retention within the estuary (Gonçalves et al. 2012). In addition, neritic copepod species displayed different vertical distribution patterns than estuarine species, with adults of neritic species showing more homogeneous distributions with depth compared to estuarine species, which were more abundant near the bottom during spring tides (Gonçalves et al. 2012). Within Mission Bay, temporal variation in the horizontal distribution of copepods has been studied on time scales of weeks to years, but vertical distribution of copepods has not been studied systematically. 
Copepods are also known to vary seasonally. Research conducted in the Lough Hyne Marine Nature Reserve (UK) showed a stark contrast in zooplankton abundance between seasons, with highest abundance in the summer and lowest in the winter (Rawlinson et al. 2004). Many copepod species, bivalve veligers, and nauplii were only abundant in summer samples. During a drought in the Mondego River estuary (Portugal), seasonal changes in zooplankton community composition became less pronounced, and the abundance of dominant copepods and cladocerans increased (Primo et al. 2009). Additionally, zooplankton distribution throughout the bay became less segregated between upstream and downstream communities. Seasonal variation also has been observed in Mission Bay, where there is a noticeable difference in species composition and abundance between winter and spring. During the wet winter, when stratification throughout the bay was lower, only some tintinnid ciliate species were found; however, during the dry summer, when the bay was more stratified, most of the identified tintinnid species were very abundant (Elliott and Kaufmann 2007).

\subsection{MISSION BAY, SAN DIEGO}

Mission Bay is a Mediterranean-climate estuary characterized by mixed semidiurnal tides that flush regions near the mouth of the bay (front bay) but have progressively less influence with increasing distance from the mouth. Water also enters Mission Bay through runoff from Tecolote and Rose Creeks as well as more than 100 storm drains surrounding the bay (Largier et al. 2003). The runoff from Tecolote Creek, which drains into the southeastern portion of the bay, has a long residence time and can persist up to a month due to the lack of tidal flushing 
in the back bay. Runoff from Rose Creek, which empties into the central portion of Mission Bay (mid bay), disperses more rapidly and has a shorter residence time (days) compared to runoff from Tecolote Creek (Largier et al. 2003).

Temperature, salinity, and nutrients, with the exception of nitrate, cycle seasonally in Mission Bay (Largier et al. 1997, Kaufmann et al. 2004, Swope 2005, Elliott and Kaufmann 2007). Temperature, salinity, and chlorophyll $a$ concentrations are generally higher in the summer (Largier et al. 1997, Kaufmann et al. 2004). Phosphate and silica are generally highest in the summer and winter and lower in the spring and fall (Kaufmann et al. 2004, Elliott and Kaufmann 2007). Surface dissolved oxygen concentrations, which are negatively correlated with temperature, also vary seasonally, with higher concentrations in the cool, wet winters and lower concentrations in the warm, dry summers (Kaufmann et al. 2004).

\subsection{RESEARCH QUESTIONS}

Estuarine copepod assemblages are well known to vary temporally and spatially, often in relation to hydrographic parameters (Wooldridge and Erasmus 1980, Kimmerer and McKinnon 1987, Hough and Naylor 1991, Laprise and Dodson 1994, Morgan et al. 1997, Rawlinson et al. 2004, Elliott and Kaufmann 2007, Xu et al. 2007, Primo et al. 2009, Ueda et al. 2010, Gonçalves et al. 2012, Intxausti et al. 2012, Kimmerer et al. 2014, Chew et al. 2015, Vineetha et al. 2015). In Mission Bay, the gradient of environmental characteristics between the front, mid and back bay provides an excellent opportunity to examine these relationships under different hydrographic regimes. The front bay is well-flushed 
by tides and rarely shows a strong influence of freshwater inputs; the mid bay shows moderate tidal influence, depending on the season and the magnitude of rainfall events; and the back bay is poorly flushed by tides. This setting is wellsuited to a study of copepod vertical and horizontal distribution over time in relation to environmental conditions. To this point, copepod research in Mission Bay has focused primarily on horizontal distributions and seasonal to annual time scales. In order to gain a better understanding of factors affecting the copepod community in Mission Bay, I addressed the following question:

How do the species composition, density, and distribution of copepods vary across three regions of Mission Bay (front, mid, back bay) over a diel cycle during spring tides, and how does that variation correlate with hydrographic conditions? 


\subsection{REFERENCES}

Chew L. L., Chong V. C., Ooi A. I., Sasekumar A. 2015. Vertical migration and positioning behavior of copepods in a mangrove estuary: interactions between tidal, diel light and lunar cycles. Estuarine, Coastal and Shelf Science 152: 142152.

Day, J.W., B.C. Crump, W.M. Kemp, and A. Yáñez-Arancibia, 2013. Estuarine Ecology, second edition. Wiley-Blackwell, New Jersey.

Elliott, D.T. and R.S. Kaufmann, 2007. Spatial and temporal variability of copepod adult, juvenile and nauplii and tintinnid ciliates in a seasonally hypersaline estuary. Estuaries and Coasts 30(3): 418-430.

Gonçalves, A.M.M., M.A. Pardal, S.C. Marques, S. Mendes, M.J. FernándezGómez, M.P. Galindo-Villardón, and U.M. Azeiteiro. 2012. Diel vertical behavior of Copepoda community (naupliar, copepodites and adults) at the boundary of a temperate estuary and coastal water. Estuarine, Coastal and Shelf Science 98: 1630 .

Hough, A.R. and E. Naylor, 1991. Field studies on retention of the planktonic copepod Eurytemora affinis in a mixed estuary. Marine Ecology Progress Series 76: $115-122$.

Intxausti, L., F. Villate, I. Uriarte, A. Iriarte, and I. Ameztoy. 2012. Size-related response of zooplankton to hydroclimatic variability and water-quality in an organically polluted estuary of the Basque coast (Bay of Biscay). Journal of Marine Systems 94: 87-96.

Kaufmann, R.S., B.C. Stransky, J. Rudolph, D.T. Elliott, R.B. Griggs, J.N. Kittinger, B.L. Swope, J.P. Bolender, M.A. Boudrias and H.A. Sarabia. 2004. Mission Bay Water and Sediment Testing Project, Final Report. City of San Diego, $101 \mathrm{pp}$.

Kimmerer, W.J. and A.D. McKinnon, 1987. Zooplankton in a marine bay. II. Vertical migration to maintain horizontal distributions. Marine Ecology Progress Series 41: 53-60.

Kimmerer W.J., E.S. Gross, and M.L. MacWilliams. 2014. Tidal migration and retention of estuary zooplankton investigated using a particle-tracking model. Limnology and Oceanography 59(3): 901-916.

Kleppel, G.S. 1993. On the diets of calanoid copepods. Marine Ecology Progress Series 99: 183-195.

Landry M.R. and R.P. Hassett, 1982. Estimating the grazing impact of marine micro-zooplankton. Marine Biology 67: 283-288. 
Landry M.R., S.L. Brown, L. Campbell, J. Constantinou, and H. Liu. 1998. Spatial patterns in phytoplankton growth and microzooplankton grazing in the Arabian Sea during monsoon forcing. Deep Sea Research Part II: Topical Studies in Oceanography 45(10-11): 2353-2368.

Laprise, R. and J.J. Dodson, 1994. Environmental variability as a factor controlling spatial patterns in distribution and species diversity of zooplankton in the St. Lawrence Estuary. Marine Ecology Progress Series 107: 67-81.

Largier, J.L., M. Carter, M. Roughan, D. Suttin, J. Helly, B. Lesh, T. Kacena, P. Ajtai, L. Clarke, D. Lucas, P. Walsh, and L. Carillo. 2003. Mission Bay Contaminant Dispersion Study Final Report. City of San Diego. 77 pp.

Largier, J.L., J.T. Hollibaugh, and S.V. Smith. 1997. Seasonally hypersaline estuaries in Mediterranean-climate regions. Estuarine, Coastal and Shelf Science 45: 789-797.

Morgan, C.A., J.R. Cordell, C.A. Simenstad. 1997. Sink or swim? Copepod population maintenance in the Columbia River estuarine turbidity-maxima region. Marine Biology 129: 309-317.

Primo, A.L, U.M. Azeiteiro, S.C. Marques, F. Martinho, and M.Â. Paradal. 2009. Changes in zooplankton diversity and distribution pattern under varying precipitation regimes in a southern temperate estuary. Estuarine, Coastal and Shelf Science 82: 341-347.

Rawlinson, K.A., J. Davinport, and D.K.A. Barnes. 2004. Vertical migration strategies with respect to advection and stratification in a semi-enclosed lough: a comparison of mero- and holozooplankton. Marine Biology 144: 935-946.

Stoecker D.K. and J.M. Capuzzo, 1990. Predation on Protozoa: its importance to zooplankton. Journal of Plankton Research 12(5): 891-901.

Strom, S.L., M.A. Brainard, J.L. Holmes, and M.B. Olson. 2001. Phytoplankton blooms are strongly impacted by microzooplankton grazing in coastal North Pacific waters. Marine Biology 138: 355-368.

Swope, B. 2005. Spatial and temporal dynamics of phytoplankton in Mission Bay over a complete annual cycle. M.S. Thesis, University of San Diego. 291 pp.

Ueda H., M. Kuwatani, and K.W. Suzuki. 2010. Tidal vertical migration of two estuarine copepods: naupliar migration and position-dependent migration. Journal of Plankton Research 32(11): 1557-1572.

Vineetha G., R. Jyothibabu, n.V. Madhu, K.K. Kusum, P.M. Sooria, A. Shivaprasad, P.D. Reny, and M.P. Deepak. 2015. Tidal influence on the diel vertical migration pattern of zooplankton in a tropical monsoonal estuary. Wetlands 356(3): 597-610. 
Wooldridge, T. and T. Erasmus, 1980. Utilization of tidal currents by estuarine zooplankton. Estuarine and Coastal Marine Science 11: 107-114.

Xu, S., W. Guizhong, L. Shaojing, G. Donghui. 2007. Preliminary study of the retention mechanism of planktonic copepods in the Jiulong Estuary in China. Acta Oceanologica Sinica 26(4): 156-163. 


\section{CHAPTER 2: COPEPOD DISTRIBUTION IN RELATION TO ENVIRONMENTAL PARAMETERS ON DIEL AND TIDAL SCALES IN MISSION BAY, SAN DIEGO, CALIFORNIA}

\subsection{INTRODUCTION}

\subsubsection{SPATIAL AND TEMPORAL VARIABILITY OF COPEPODS}

Copepods are key components of marine ecosystems and play important functional roles in estuarine ecosystem dynamics (e.g., Kleppel 1993, Day et al. 2013). The species of copepods present in an estuary can reflect hydrographic conditions, and abiotic conditions can cause zooplankton variability. For example, copepod concentrations were highest in the least stratified portions of the St. Lawrence Estuary (Laprise and Dodson 1994). In Mission Bay, San Diego, when there were large inputs of fresh water that decreased salinity and increased nutrients within the bay, more copepod species were present (Elliott and Kaufmann 2007). However, when the estuary was inversely stratified, more tintinnid species were abundant and relatively few copepods were observed (Elliott and Kaufmann 2007).

Copepod patchiness also can be related to food availability, as many copepods feed on phytoplankton (Landry and Hassett 1982, Landry et al. 1998, Stoecker and Capuzzo 1990, Strom et al. 2001). However, the lack of phytoplankton can also affect copepod abundance and species composition.

Toward the end of the summer in Mission Bay, when bloom conditions were still favorable but food was scarce, smaller copepods tended to prevail and were present where phytoplankton abundance was higher (Elliott and Kaufmann 2007). 
Tides are also very important in contributing to copepod patchiness. In Westernport Bay (Australia), vertical position in the water column of Acartia tranteri, was significantly affected by tides, and copepod movement in relation to the tides aided their retention within the bay (Kimmerer and McKinnon 1987). A model of copepod behavior found that particles exhibiting realistic copepod migratory behavior were shallower in the water column during flood tides and deeper during ebb tides (Kimmerer et al. 2014). This behavior led to retention of migratory particles within the estuary. By contrast, most of the passive particles in their model did not remain in the estuary and were transported seaward. While copepod patchiness was observed, this pattern may have resulted from interactions between the particles' vertical movements and the bathymetry of the estuary. Similar results were observed in the Conwy Estuary (North Wales), where copepod abundance was greatest in the seaward portion of the estuary during flood tide and lowest in the landward portion of the estuary during ebb tide (Hough and Naylor 1991). In the Mantang Estuary (China), more estuarine copepods were abundant shallow in the water column during the night time flood tide, while more marine copepods were present deep in the water column during the night time ebb tide (Chew et al. 2015). It was proposed that the estuarine copepod species were migrating in a way that favored retention in the estuary, and that the marine species were acting in a way that led to advection from the estuary (Chew et al. 2015). The tidal migration behavior of copepods for estuarine retention has also been observed in the Jiulong Estuary (China, Xu et al. 2007), 
the Columbia River Estuary (United States, Morgan et al. 1997), and the Sundays River Estuary (South Africa, Wooldridge and Erasmus 1980).

Copepod vertical migration in estuaries can also be affected by predation. In the Chikugo River Estuary (Japan), tidal migration for retention was prominent during day tides (Ueda et al. 2010). However, at night, the calanoid copepod Pseudodiaptomus inopinus migrated in a manner related more closely to predator avoidance than estuarine retention. In the Cochin Backwaters Estuary (India), tides had less effect on Decapoda (Luciferidae), Mysidacea, and Amphipoda, and diel vertical migration for predator avoidance was observed to be more prominent in these zooplankton (Vineetha et al. 2015).

Copepod abundance and species composition also exhibit temporal variation on a variety of time scales. In the mesotidal Mondego River estuary (Portugal), vertical distributions of copepods were related primarily to water depth and tidal currents, though day-night patterns were important during the summer (Gonçalves et al. 2012). Most of the copepod species examined in the study had high densities during spring tides in winter but were more abundant during neap tides throughout the rest of the year. Early life stages of these copepods were most abundant near the bottom of the estuary during ebb tides, which should enhance retention within the estuary. In addition, neritic copepod species displayed different vertical distribution patterns than estuarine species, with adults of neritic species showing more homogeneous distributions with depth compared to estuarine species, which were more abundant near the bottom during 
spring tides (Gonçalves et al. 2012). Within Mission Bay, temporal variation in the horizontal distribution of copepods has been studied on time scales of weeks to years (Swope 2005, Elliott 2007, Kittinger 2006, Griggs 2009), but vertical distribution of copepods has not been studied systematically.

In Mission Bay, copepod distributions across regions of the bay have been characterized over multiple annual cycles. Copepods in the back bay were predominantly estuarine species and primarily holoplankton, with increasing densities of neritic species and larval forms of benthic species in the mid and front bay (Elliott and Kaufmann 2007). The front bay species assemblage, in particular, often was dominated by larvae as well as neritic copepods (Elliott and Kaufmann 2007). These results suggest decreasing exchange with the coastal ocean in relation to distance from the mouth, and that copepod behavior might differ in different regions of the bay in ways that enhance retention and in relation to a particular lifestyle.

Relatively few studies have looked at copepod vertical distribution across a gradient of tidal influence. Additionally within estuaries, especially Mediterranean-climate estuaries, very few studies have looked at the relationship between hydrographic parameters and copepod vertical distribution. Prior to this study, vertical distributions of copepods within broad regions of Mission Bay and in relation to environmental parameters, including tidal conditions, had not been examined. This study aims to address the following questions: How do the species composition, density, and distribution of copepods vary vertically over a diel 
cycle during spring tides and how does this variation relate to hydrographic parameters? Additionally, how does this variation differ among three locations across the bay (front, mid, and back bay)?

\subsection{MATERIALS AND METHODS}

\subsubsection{STUDY SITE}

Mission Bay is a Mediterranean-climate estuary characterized by mixed semidiurnal tides that flush regions near the mouth of the bay (front bay) but have progressively less influence with increasing distance from the mouth. Water also enters Mission Bay through runoff from Tecolote (back bay) and Rose (mid bay) Creeks as well as more than 100 storm drains surrounding the bay (Largier et al. 2003). The runoff from Tecolote Creek, which drains into the southeastern portion of the bay, has a long residence time and can persist up to a month due to the lack of tidal flushing in the back bay (Largier et al. 2003).

The bay is relatively shallow with depths ranging from less than $1 \mathrm{~m}$ in the back bay to $8 \mathrm{~m}$ in the front bay at high tide. Temperature, salinity, and chlorophyll $a$ concentrations are generally higher in the summer (Largier et al. 1997, Kaufmann et al. 2004). Phosphate and silica are generally higher in the summer and winter and lower in the spring and fall (Kaufmann et al. 2004, Elliott and Kaufmann 2007). Surface dissolved oxygen concentrations, which are negatively correlated with temperature, also vary seasonally, with higher concentrations in the cool, wet winters and lower concentrations in the warm, dry summers (Kaufmann et al. 2004). 
Figure 1. Mission Bay, San Diego. Study sites, Ventura Point (front bay), Fiesta Bay (mid bay) and Hilton Dock (back bay), are marked with yellow circles. Tidal height buoy (Crown Point) is marked in red. 


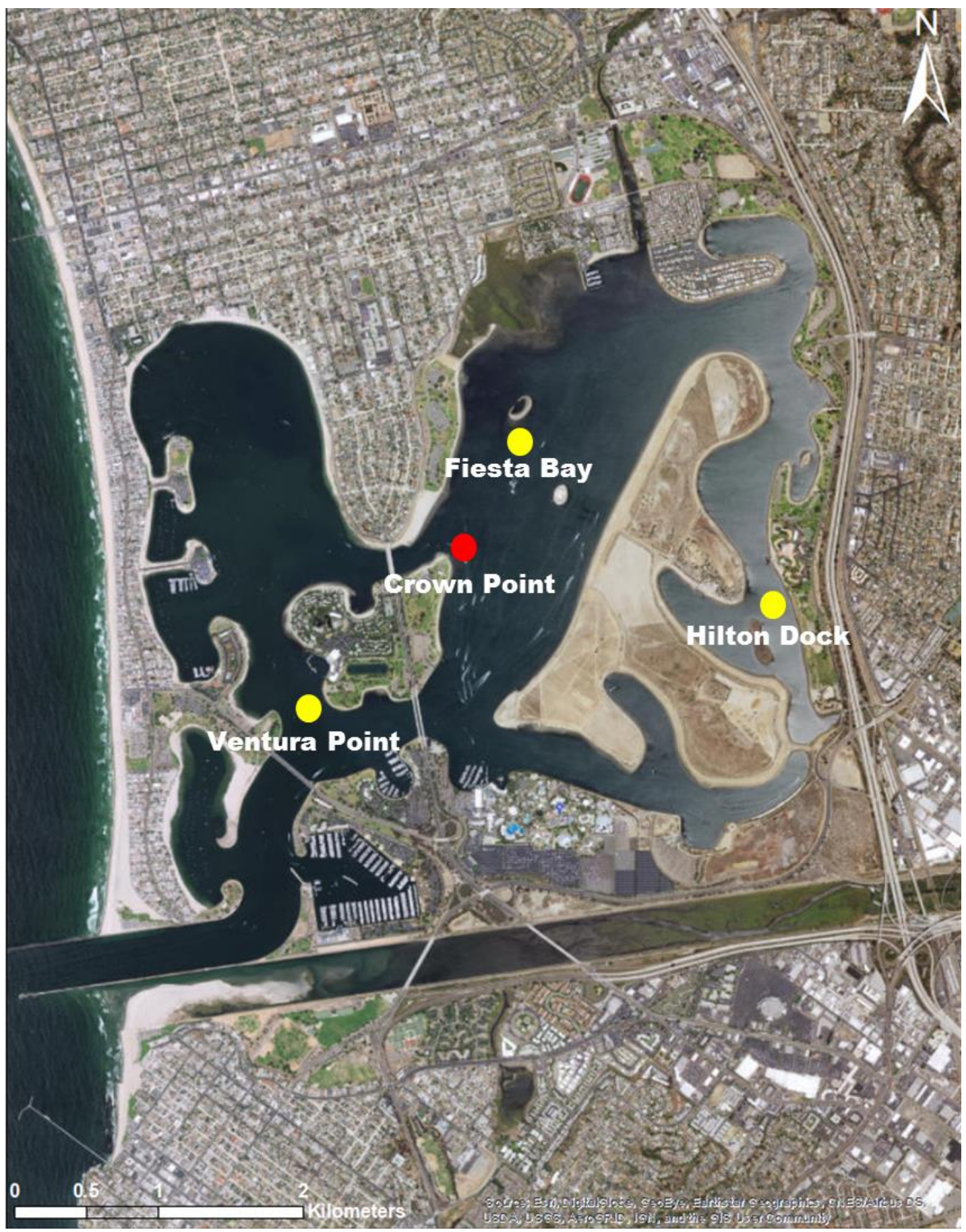




\subsubsection{FIELD METHODS}

Research was conducted over a three month period surrounding full moon spring tides in Mission Bay, San Diego, from July through September 2016

(Table 1). There were three sampling sites within the bay: Ventura Point, near the mouth (front bay); Fiesta Bay, in the middle of the bay (mid bay); and Hilton Dock, in the eastern portion of the bay (back bay) (Figure 1). To encompass different tidal phases during the diel cycle, each site was sampled every two hours over a 24 hour period. At each site, one sample was collected at each of two depths (just below the surface and $0.5 \mathrm{~m}$ above the bottom) during a sampling event. There were 13 sampling events per site in a sampling period, and a total of 3 sampling periods per location over the course of this study. To examine copepod (nauplii, juveniles, and adults) abundance and species composition, a plankton pump was deployed at these same two depths for 10 minutes at a time, pumping $\sim 2 \mathrm{~m}^{3}$ of water per sample. The stream of water from the pump's output hose was filtered through a $100 \mu \mathrm{m}$ mesh net, and the material collected was rinsed into a $500 \mathrm{ml}$ opaque polyethlyene bottle. A digital multimeter (YSI 6600 V2 multi parameter sonde) was used to collect depth profiles of hydrographic parameters (salinity and temperature) at each site. Water samples were collected at the two pump depths using a Van Dorn bottle, and temperature and salinity were measured with thermometers and refractometers, respectively. In the lab, water samples were analyzed for chlorophyll and phaeopigment concentrations. These samples were stored in brown polyethylene bottles prior to analysis, to reduce the effects of light on water sample chemistry. 
Table 1. Date and location of each 24-hour sampling event. Each sampling event started at $8 \mathrm{PM}$ and ended the next night after the $8 \mathrm{PM}$ sample. Full moon is indicated by $*$. 


\begin{tabular}{|llll|}
\hline Date & Location & Sunrise & Sunset \\
\hline July 16-17 & Ventura Point & 5:54 am & 8:04 pm \\
July 18-19* & Fiesta Bay & $5: 56 \mathrm{am}$ & $8: 03 \mathrm{pm}$ \\
July 20-21 & Hilton Dock & $5: 57 \mathrm{am}$ & $8: 01 \mathrm{pm}$ \\
\hline August 15-16 & Ventura Point & $6: 16 \mathrm{am}$ & $7: 38 \mathrm{pm}$ \\
August 17-18* & Fiesta Bay & $6: 17 \mathrm{am}$ & $7: 36 \mathrm{pm}$ \\
August 19-20 & Hilton Dock & $6: 19 \mathrm{am}$ & $7: 33 \mathrm{pm}$ \\
\hline September 13-14 & Ventura Point & $6: 36 \mathrm{am}$ & $7: 00 \mathrm{pm}$ \\
September 15-16** & Fiesta Bay & $6: 37 \mathrm{am}$ & $6: 57 \mathrm{pm}$ \\
September 17-18 & Hilton Dock & $6: 39 \mathrm{am}$ & $6: 54 \mathrm{pm}$ \\
\hline
\end{tabular}




\subsubsection{LABORATORY METHODS}

While many types of zooplankton were collected in this study, only copepods were counted and presented in this research. For the purpose of this study, copepods were defined as adult and juvenile stages of copepods, whereas "nauplii" refers to copepod nauplii. Each zooplankton sample was preserved in $3.7 \%$ formalin, buffered with borax, and stored in a $500 \mathrm{~mL}$ glass bottle. The samples were examined using a Sedgewick-Rafter slide under a compound microscope at 100x magnification $\left(2.32 \mathrm{~mm}^{3}\right.$ per field of view). Each individual organism was counted and identified to the lowest taxonomic level. At least two slides were prepared for each sample, with 10 randomly-selected non-overlapping fields of view per slide examined until at least 100 organisms were counted or until a rarefaction curve indicated that the number of species observed $v s$. the number of individuals counted approached an asymptote. If no organisms were observed in 10 fields of view, the entire slide $(1 \mathrm{~mL})$ was examined, and all organisms on the slide were enumerated and identified. The total volume examined from each sample ranged from 0.05 to $5 \mathrm{~mL}$.

Water samples were filtered immediately after returning to the lab. To measure photosynthetic pigment concentrations, $250 \mathrm{~mL}$ of water was filtered through a GF/F glass fiber filter. After filtration, filters were folded in half twice, wrapped in aluminum foil and frozen $\left(-80^{\circ} \mathrm{C}\right)$ for analysis. Analytical methods followed those of Holm-Hansen et al. (1965) and Lorenzen (1966). This analysis consisted of extracting the filters by soaking them in a $90 \%$ acetone solution for 24 hours. Chlorophyll and phaeopigments were measured using a Turner Designs 
fluorometer (model 10-AU, $440 \mathrm{~nm}$ excitation wavelength, $685 \mathrm{~nm}$ fluorescence detection wavelength). Total photosynthetic pigment concentrations for each sample were calculated as the sum of chlorophyll and phaeopigment concentrations.

\subsubsection{DATA ANALYSIS}

Tidal height was calculated from buoys near Scripps Pier (station ID 9410230, 32.8669 N, 117.2571 W), near the coast just north of Mission Bay, and Crown Point (station ID 9410191) in the front/mid portion of Mission Bay. Tide data for Scripps Pier were available every 30 minutes, while the Crown Point data were only presented as high and low tide measurements. A linear regression between Scripps Pier and Crown Point high tides was performed to approximate the tidal height for Mission Bay. The regression equation was used to estimate tidal height with half hour resolution for Crown Point. These data were used for subsequent statistical analysis. Supplemental data from field thermometer measurements of water samples collected near the surface and $0.5 \mathrm{~m}$ above bottom were used to fill in missing data from the sonde. It is important to note that these values were used to look at trends rather than absolute values. The water column was relatively homogeneous in terms of temperature, salinity, and chlorophyll concentration, so only surface values were used for visual representations of trends.

For each time and depth at each site, Shannon-Wiener diversity, evenness $\left(\mathrm{H} / \mathrm{H}_{\max }\right)$, and taxonomic richness were calculated. Kruskal-Wallis ANOVAs 
were used to examine diversity, evenness and taxonomic richness differences among the three study sites over the three month sampling period, and to determine the relationship between tidal phase and time of day, and copepod density and diversity. To perform these analyses, vertical differences in copepod adult, juvenile and nauplii density were used, in which bottom densities were subtracted from surface densities at each time for each location. Post-hoc Dunn's tests were performed on the significant relationships identified with the KruskalWallis ANOVAs. Pearson's correlations between hydrographic parameters and copepod adult, juvenile and nauplii densities were only performed on near-surface and bottom data for temperature, salinity, total photosynthetic pigments, and tidal height.

\subsection{RESULTS}

The predominant species throughout the bay during July to September 2016 was Oithona similis. Over the three sampling periods, the relative abundance of Oithona similis increased from July to August at each site, and increased from August to September at Ventura Point (Table 2). In addition, the total combined percentage of the five most dominant taxa increased over time at each site, with highest percentages in September. Each month, the total percentage of the copepod assemblage made up of the top 5 taxa was lowest at Ventura Point and increased with increasing distance into the bay. 
Table 2. Five most numerically dominant taxa at each site during each month sampled and mean \pm std dev copepod adult, juvenile and nauplii density $\left(\mathrm{m}^{-3}\right)$ for each sampling period. 


\begin{tabular}{|c|c|c|c|c|c|}
\hline \multicolumn{2}{|c|}{ Ventura Point } & \multicolumn{2}{|c|}{ Fiesta Bay } & \multicolumn{2}{|c|}{ Hilton Dock } \\
\hline July & $\%$ & & $\%$ & & $\%$ \\
\hline Oithona similis & 39.21 & $\begin{array}{l}\text { Oithona similis } \\
\text { Oithona }\end{array}$ & 73.31 & Oithona similis & 76.38 \\
\hline Copepod Nauplii & 18.86 & $\begin{array}{l}\text { oculata } \\
\text { Copepod }\end{array}$ & 10.27 & $\begin{array}{l}\text { Oithona nana } \\
\text { Oithona }\end{array}$ & 13.00 \\
\hline Oithona oculata & 11.99 & $\begin{array}{l}\text { Nauplii } \\
\text { Copepod }\end{array}$ & 4.76 & $\begin{array}{l}\text { oculata } \\
\text { Copepod }\end{array}$ & 6.28 \\
\hline Acartia clausi & 7.98 & Juveniles & 3.84 & $\begin{array}{l}\text { Nauplii } \\
\text { Copepod }\end{array}$ & 1.78 \\
\hline Copepod Juveniles & 7.84 & Oithona nana & 3.70 & Juveniles & 1.24 \\
\hline Top 5 & 85.88 & & 95.88 & & 98.68 \\
\hline $\begin{array}{l}\text { Mean Density } \\
\text { August }\end{array}$ & $\begin{array}{r}150,000 \\
( \pm 170,000)\end{array}$ & & $\begin{array}{r}630,000 \\
( \pm 380,000)\end{array}$ & & $\begin{array}{r}850,000 \\
( \pm \mathbf{3 0 0 , 0 0 0})\end{array}$ \\
\hline Oithona similis & 56.34 & $\begin{array}{l}\text { Oithona similis } \\
\text { Clausocalanus }\end{array}$ & 88.15 & $\begin{array}{l}\text { Oithona similis } \\
\text { Oithona }\end{array}$ & 90.83 \\
\hline Copepod Nauplii & 18.57 & $\begin{array}{l}\text { spp. } \\
\text { Copepod }\end{array}$ & 4.03 & $\begin{array}{l}\text { oculata } \\
\text { Copepod }\end{array}$ & 4.18 \\
\hline Clausocalanus spp. & 7.60 & $\begin{array}{l}\text { Nauplii } \\
\text { Oithona }\end{array}$ & 2.99 & $\begin{array}{l}\text { Juveniles } \\
\text { Copepod }\end{array}$ & 1.84 \\
\hline Oithona nana & 6.37 & $\begin{array}{l}\text { oculata } \\
\text { Copepod }\end{array}$ & 2.10 & $\begin{array}{l}\text { Nauplii } \\
\text { Clausocalanus }\end{array}$ & 1.84 \\
\hline Oithona oculata & 5.94 & Juveniles & 1.80 & spp. & 1.09 \\
\hline $\begin{array}{l}\text { Total Percent of } \\
\text { Top } 5\end{array}$ & 94.82 & & 99.07 & & 99.78 \\
\hline Mean Density & $\begin{array}{r}240,000 \\
( \pm 290,000)\end{array}$ & & $\begin{array}{r}730,000 \\
( \pm 470,000)\end{array}$ & & $\begin{array}{r}75,000 \\
(+65,000)\end{array}$ \\
\hline September & & & & & \\
\hline Oithona similis & 76.53 & $\begin{array}{l}\text { Oithona similis } \\
\text { Oithona }\end{array}$ & 84.65 & $\begin{array}{l}\text { Oithona similis } \\
\text { Oithona }\end{array}$ & 88.28 \\
\hline Clausocalanus spp. & 9.68 & $\begin{array}{l}\text { oculata } \\
\text { Copepod }\end{array}$ & 5.60 & $\begin{array}{l}\text { oculata } \\
\text { Copepod }\end{array}$ & 4.48 \\
\hline Copepod Nauplii & 6.07 & $\begin{array}{l}\text { Juveniles } \\
\text { Clausocalanus }\end{array}$ & 3.38 & $\begin{array}{l}\text { Juveniles } \\
\text { Copepod }\end{array}$ & 3.89 \\
\hline Copepod Juveniles & 2.11 & $\begin{array}{l}\text { spp. } \\
\text { Copepod }\end{array}$ & 3.12 & $\begin{array}{l}\text { Nauplii } \\
\text { Clausocalanus }\end{array}$ & 2.26 \\
\hline $\begin{array}{l}\text { Oithona oculata } \\
\text { Total Percent of }\end{array}$ & 2.09 & Nauplii & 3.12 & spp. & 1.00 \\
\hline Top 5 & 96.48 & & 99.87 & & 99.91 \\
\hline Mean Density & $\begin{array}{r}180,000 \\
( \pm 280,000)\end{array}$ & & $\begin{array}{r}290,000 \\
(+140,000)\end{array}$ & & $\begin{array}{r}130,000 \\
( \pm \mathbf{8 8 , 0 0 0}) \\
\end{array}$ \\
\hline
\end{tabular}


Near-bottom copepod densities were highest at night at Ventura Point each month, specifically during night ebb tides, and lowest during day flood tides (Figure 2). At Fiesta Bay and Hilton Dock, surface densities generally were higher during early evening. At Fiesta Bay, the highest copepod densities shifted from surface to near-bottom in the early morning and remained highest near the bottom throughout the day. Copepod densities generally increased with increasing tidal height at Fiesta Bay and Hilton Dock.

Overall, nauplii densities were relatively low compared to copepod densities. Each month, nauplii densities were highest at Ventura Point, peaking in August (Fig. 2B). Densities in September were very low across all sites (Fig. 2C). There was no consistent relationship between nauplii densities and tidal phase across months and sites. 
Figure 2. Copepod (adult and juvenile) and nauplii densities $\left(\times 10^{6} \mathrm{~m}^{-3}\right)$ just below the surface and $0.5 \mathrm{~m}$ above bottom over 24 hour sampling periods during July (A), August (B), and September (C) 2016 at each site: Ventura Point (VP), Fiesta Bay (FB), and Hilton Dock (HD). Black curve shows tidal height, gray panels indicate night time. 


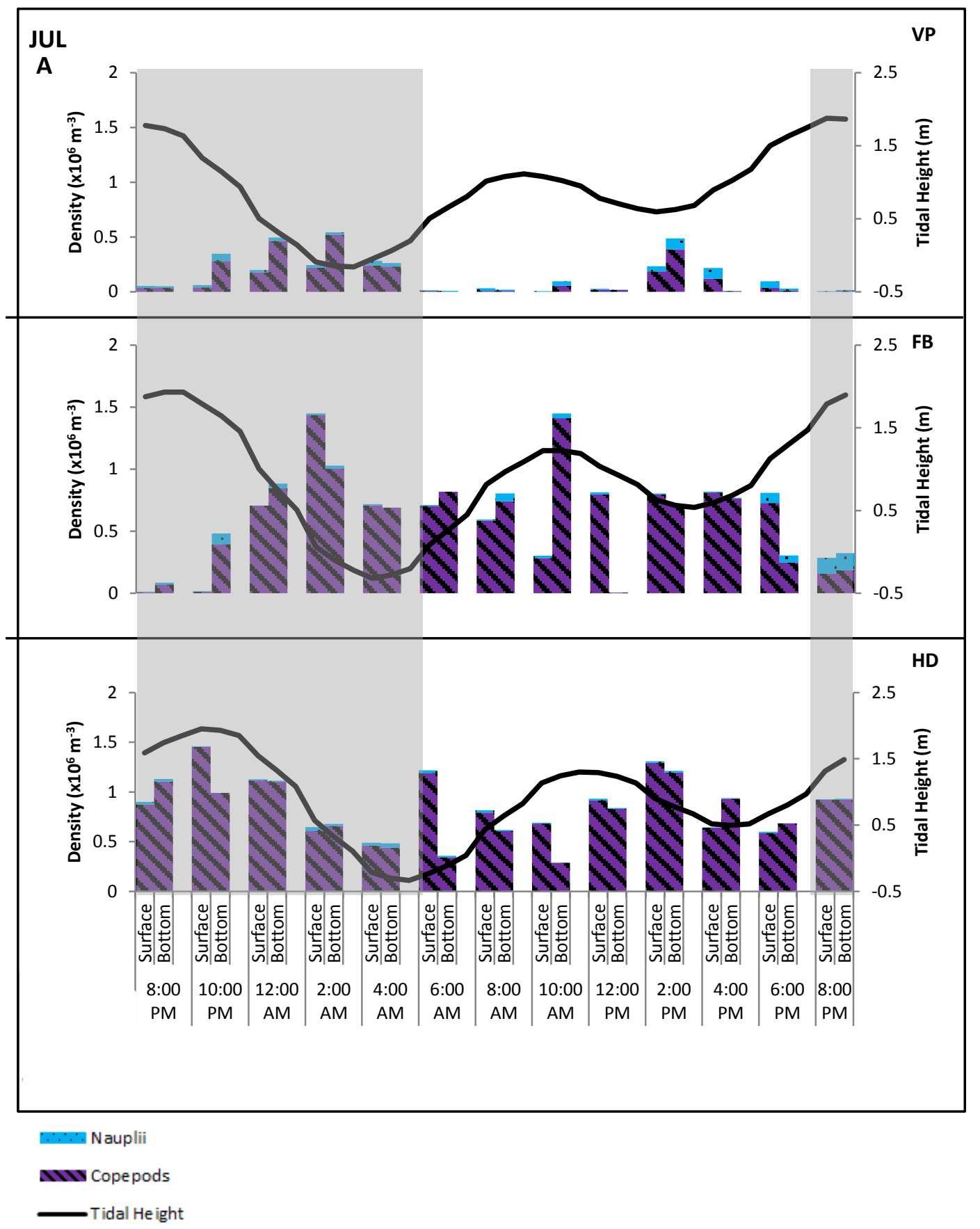




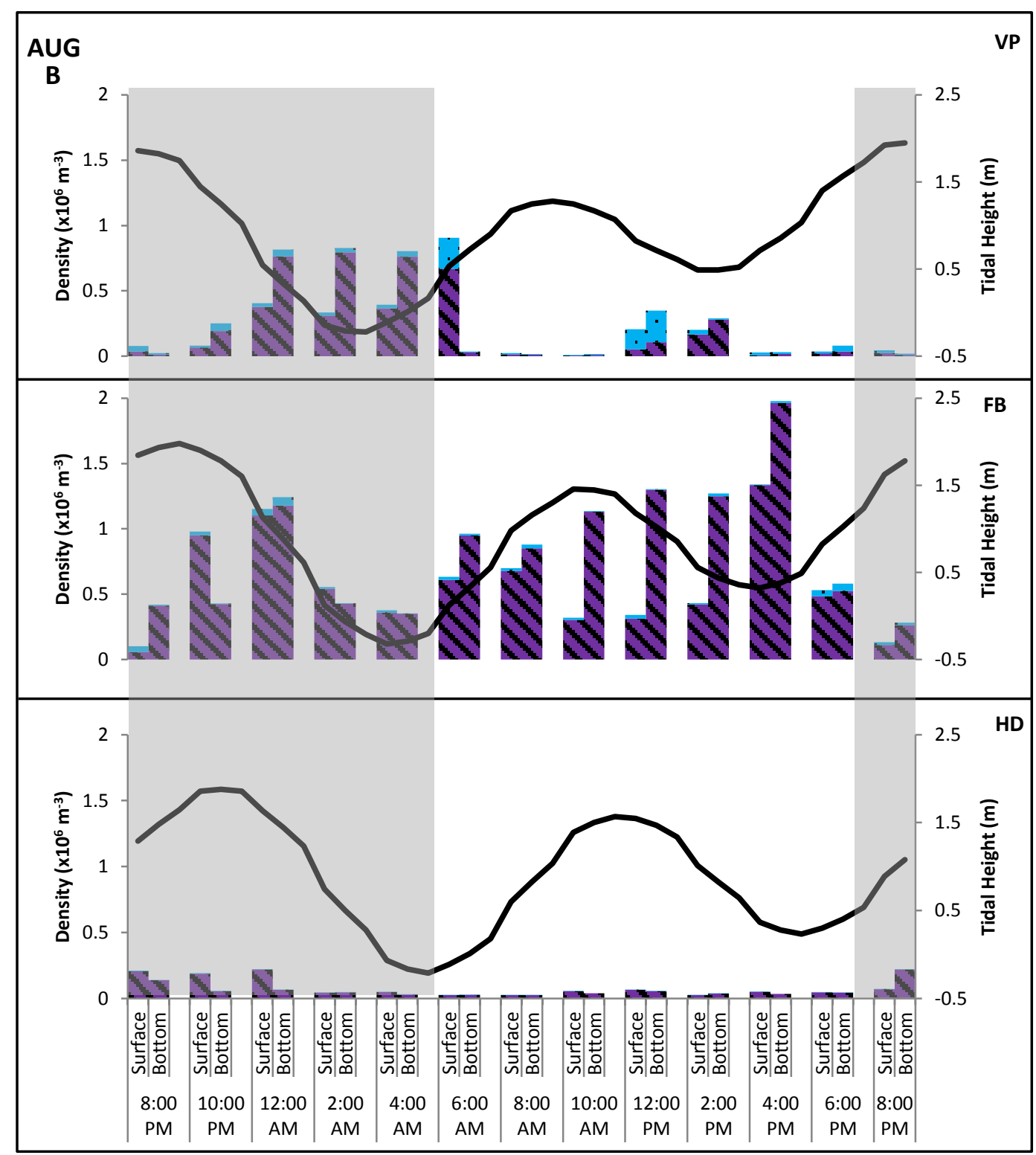

$\because \because$ Nauplii

DV Copepods

—_Tidal He ight 


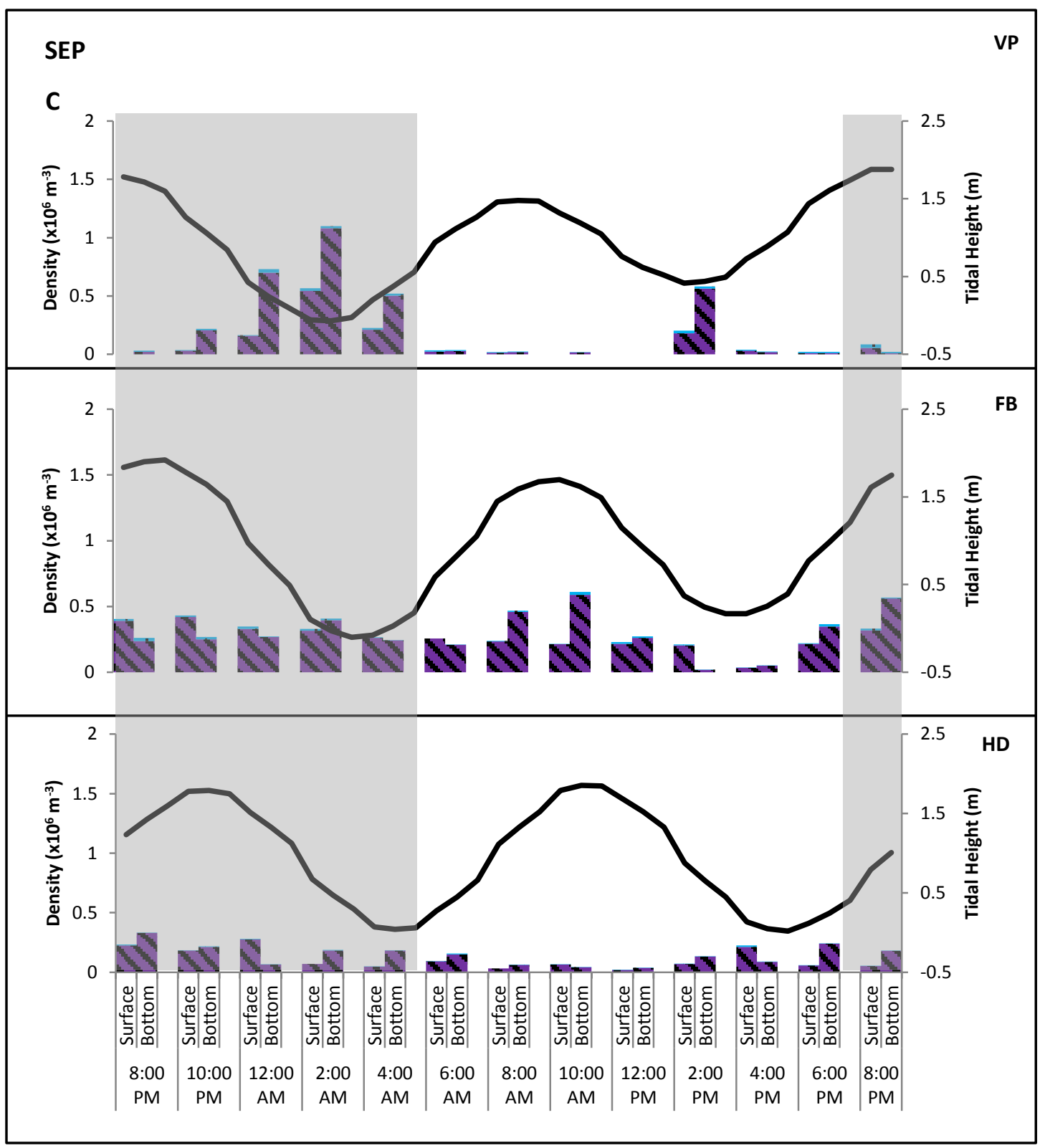

$\because \cdots$ Nauplii

NII Copepods

Tidal He ight 
Each month, mean species diversity, evenness and richness were highest at Ventura Point and decreased with increasing distance into the bay (Table 3). To examine relationships between day-night/tidal phase combinations (day/ebb, day/flood, night/ebb, night/flood) and copepod adult, juvenile and nauplii density, diversity, evenness, and richness at each site for each month, surface and nearbottom samples were pooled for Kruskal-Wallis tests (Table 4). Copepod adult, juvenile and nauplii density for all months combined showed a significant difference among day-night/tidal phase combinations at Ventura Point $(\mathrm{p}=0.02)$. However, no significant differences were detected when the same analysis was performed for each month individually. Based on the results of a post-hoc Dunn's test, there was a significant difference in copepod adult, juvenile and nauplii densities between day/flood and night/ebb $(\mathrm{p}<0.001)$, with the night/ebb densities being higher than the day/flood densities (Table 5). Significant differences among day-night/tidal phase combinations and total density were detected at Fiesta Bay in August ( $\mathrm{p}=0.03$ ) and among day-night/tidal phase combinations and species richness at Ventura Point in July ( $\mathrm{p}=0.05$ ). Post-hoc Dunn's tests showed a significant difference between day/ebb and night/ebb for copepod densities in August at Fiesta Bay $(\mathrm{p}=0.002)$, and species richness in July at Ventura Point $(\mathrm{p}=0.01)$ (Table 5). In August, day/ebb densities were higher than night/ebb densities. In July, species richness was higher during night/ebb than day/ebb. 
Table 3. Mean ( \pm std dev), Shannon-Wiener index, evenness $\left(\mathrm{H} / \mathrm{H}_{\max }\right)$, and species richness for each month and site: Ventura Point (VP), Fiesta Bay (FB), Hilton Dock (HD). 


\begin{tabular}{|c|c|c|c|c|}
\hline Month & Site & Diversity & Evenness & Richness \\
\hline \multirow[t]{3}{*}{ July } & VP & $1.52 \pm 0.26$ & $0.78+0.10$ & $7.19 \pm 1.50$ \\
\hline & FB & $0.96+0.48$ & $0.58 \pm 0.22$ & $5.12 \pm 1.21$ \\
\hline & HD & $0.81 \pm 0.14$ & $0.48 \pm 0.08$ & $5.58 \pm 1.10$ \\
\hline \multirow[t]{3}{*}{ August } & VP & $1.34 \pm 0.33$ & $0.67 \pm 0.12$ & $7.38 \pm 1.55$ \\
\hline & FB & $0.58 \pm 0.36$ & $0.34 \pm 0.17$ & $5.31 \pm 1.35$ \\
\hline & HD & $0.43 \pm 0.26$ & $0.28 \pm 0.14$ & $4.50 \pm 1.03$ \\
\hline \multirow[t]{3}{*}{ September } & VP & $1.25 \pm 0.40$ & $0.63 \pm 0.16$ & $7.38 \pm 1.65$ \\
\hline & FB & $0.59 \pm 0.20$ & $0.37 \pm 0.12$ & $4.92 \pm 0.80$ \\
\hline & HD & $0.46+0.17$ & $0.31 \pm 0.09$ & $4.50+0.86$ \\
\hline
\end{tabular}


Table 4. Kruskal-Wallis ANOVA results for copepod adult, juvenile and nauplii densities, Shannon-Wiener diversity, evenness $\left(\mathrm{H} / \mathrm{H}_{\max }\right)$ and species richness in relation to combined tidal phase and diel cycle: day/flood, day/ebb, night/flood, night/ebb. $\mathrm{df}=3$. Shaded cells indicate $\mathrm{p}$-values $\leq 0.05$. 


\begin{tabular}{|c|c|c|c|c|c|c|c|c|}
\hline Site & \multicolumn{2}{|c|}{ Total Density } & \multicolumn{2}{|c|}{$\underline{\text { S-W Diversity }}$} & \multicolumn{2}{|c|}{ Evenness } & \multicolumn{2}{|c|}{ Richness } \\
\hline $\begin{array}{l}\text { All } \\
\text { Months }\end{array}$ & $\begin{array}{l}\text { Chi- } \\
\text { squared }\end{array}$ & $\mathrm{p}$ & $\begin{array}{l}\stackrel{\text { Chi- }}{\text { squared }} \\
\underline{\text { qun }}\end{array}$ & $\mathrm{p}$ & $\begin{array}{l}\text { Chi- } \\
\text { squared }\end{array}$ & $\mathrm{p}$ & $\begin{array}{l}\text { Chi- } \\
\text { squared }\end{array}$ & $\mathrm{p}$ \\
\hline $\begin{array}{l}\text { Ventura } \\
\text { Point }\end{array}$ & 10.31 & 0.02 & 1.86 & 0.60 & 3.92 & 0.27 & 1.75 & 0.63 \\
\hline Fiesta Bay & 3.7 & 0.30 & 3.88 & 0.27 & 2.48 & 0.48 & 5.35 & 0.15 \\
\hline $\begin{array}{l}\text { Hilton } \\
\text { Dock }\end{array}$ & 3.3 & 0.35 & 5.19 & 0.16 & 1.77 & 0.62 & 3.82 & 0.28 \\
\hline
\end{tabular}

\begin{tabular}{|c|c|c|c|c|c|c|c|c|}
\hline Site & \multicolumn{2}{|c|}{ Total Density } & \multicolumn{2}{|c|}{ S-W Diversity } & \multicolumn{2}{|c|}{ Evenness } & \multicolumn{2}{|c|}{ Richness } \\
\hline$\overline{\text { Jul }}$ & $\underset{\text { squared }}{\text { Chi- }}$ & $\mathrm{p}$ & $\begin{array}{l}\text { Chi- } \\
\text { squared }\end{array}$ & $\mathrm{p}$ & $\begin{array}{l}\text { Chi- } \\
\text { squared }\end{array}$ & $\mathrm{p}$ & $\begin{array}{l}\text { Chi- } \\
\text { squared }\end{array}$ & $\mathrm{p}$ \\
\hline $\begin{array}{l}\text { Ventura } \\
\text { Point }\end{array}$ & 6.35 & 0.10 & 1.41 & 0.70 & 2.61 & 0.46 & 7.64 & 0.05 \\
\hline Fiesta Bay & 0.57 & 0.90 & 2.04 & 0.56 & 0.79 & 0.85 & 0.94 & 0.81 \\
\hline $\begin{array}{l}\text { Hilton } \\
\text { Dock }\end{array}$ & 3.16 & 0.37 & 2.58 & 0.46 & 6.60 & 0.09 & 5.18 & 0.16 \\
\hline
\end{tabular}

\begin{tabular}{|c|c|c|c|c|c|c|c|c|}
\hline Site & \multicolumn{2}{|c|}{ Total Density } & \multicolumn{2}{|c|}{$\underline{\text { S-W Diversity }}$} & \multicolumn{2}{|c|}{$\underline{\text { Evenness }}$} & \multicolumn{2}{|c|}{$\underline{\text { Richness }}$} \\
\hline$\overline{\text { Aug }}$ & $\begin{array}{l}\text { Chi- } \\
\text { squared }\end{array}$ & $\mathrm{p}$ & $\begin{array}{c}\text { Chi- } \\
\text { squared }\end{array}$ & $\mathrm{p}$ & $\begin{array}{c}\text { Chi- } \\
\text { squared }\end{array}$ & $\mathrm{p}$ & $\begin{array}{c}\text { Chi- } \\
\text { squared }\end{array}$ & $\mathrm{p}$ \\
\hline $\begin{array}{l}\text { Ventura } \\
\text { Point }\end{array}$ & 3.42 & 0.33 & 3.04 & 0.39 & 1.26 & 0.74 & 1.63 & 0.65 \\
\hline Fiesta Bay & 9.08 & 0.03 & 6.19 & 0.10 & 5.23 & 0.15 & 6.44 & 0.09 \\
\hline $\begin{array}{l}\text { Hilton } \\
\text { Dock }\end{array}$ & 1.36 & 0.72 & 2.33 & 0.51 & 2.22 & 0.53 & 2.98 & 0.40 \\
\hline
\end{tabular}

\begin{tabular}{|c|c|c|c|c|c|c|c|c|}
\hline Site & \multicolumn{2}{|c|}{ Total Density } & \multicolumn{2}{|c|}{ S-W Diversity } & \multicolumn{2}{|c|}{ Evenness } & \multicolumn{2}{|c|}{$\underline{\text { Richness }}$} \\
\hline Sep & $\underset{\text { squared }}{\text { Chi- }}$ & $\underline{P}$ & $\begin{array}{c}\text { Chi- } \\
\text { squared }\end{array}$ & $\underline{\mathrm{P}}$ & $\begin{array}{l}\text { Chi- } \\
\text { squared }\end{array}$ & $\underline{p}$ & $\begin{array}{l}\text { Chi- } \\
\text { squared }\end{array}$ & $\mathrm{p}$ \\
\hline $\begin{array}{l}\text { Ventura } \\
\text { Point }\end{array}$ & 4.67 & 0.20 & 1.69 & 0.64 & 1.59 & 0.66 & 0.53 & 0.91 \\
\hline Fiesta Bay & 1.96 & 0.58 & 2.72 & 0.44 & 1.14 & 0.77 & 3.45 & 0.33 \\
\hline $\begin{array}{l}\text { Hilton } \\
\text { Dock }\end{array}$ & 1.89 & 0.60 & 2.40 & 0.49 & 1.40 & 0.71 & 2.42 & 0.49 \\
\hline
\end{tabular}


Table 5. Dunn's post-hoc test for copepod adult, juvenile and nauplii densities for all months at Ventura Point (All VP) and in August at Fiesta Bay (Aug FB), and July species richness at Ventura Point (Jul VP) in relation to tidal phase and diel cycle: day/flood, day/ebb, night/flood, night/ebb. Shaded cells indicate p-values $\leq$ 0.01 . 


\begin{tabular}{|c|c|c|c|}
\hline & $\begin{array}{l}\text { All VP Total } \\
\text { Density }\end{array}$ & $\begin{array}{l}\text { Aug FB Total } \\
\text { Density }\end{array}$ & $\begin{array}{l}\text { Jul VP } \\
\text { Richness }\end{array}$ \\
\hline $\begin{array}{l}\text { Time of Day/Tidal } \\
\text { Phase }\end{array}$ & $\mathrm{p}$-value & $\mathrm{p}$-value & p-value \\
\hline Day/Flood: Day/Ebb & 0.12 & 0.07 & 0.24 \\
\hline Night/Flood: Night/Ebb & 0.03 & 0.17 & 0.04 \\
\hline Day/Flood: Night/Flood & 0.30 & 0.27 & 0.26 \\
\hline Day/Ebb: Night/Ebb & 0.07 & 0.002 & 0.01 \\
\hline Day/Ebb: Night/Flood & 0.29 & 0.02 & 0.46 \\
\hline Day/Flood: Night/Ebb & $<0.001$ & 0.05 & 0.02 \\
\hline
\end{tabular}


Temperature and salinity were highest at all three sites in July and decreased through September (Figure 3). Each month, both parameters were lowest at Ventura Point in the front of the bay and increased with distance into the bay. At Ventura Point and Fiesta Bay, temperature and salinity increased during ebb tide and decreased during flood tide. At Hilton Dock, temperature decreased during night ebb tides but increased during day ebb tides. Salinity increased during ebb tides and decreased during flood tides. Temperature was lowest at each site from 6-8 am and highest at Ventura Point and Fiesta Bay around 2 pm and at Hilton Dock around $4 \mathrm{pm}$ each month. Salinity at each site was highest from 2-4 am (Figure 3).

Highest pigment concentrations were measured in July at Ventura Point (Fig. 3A), in August at Ventura Point and Hilton Dock (Fig. 3D and 3F), and in September at Hilton Dock (Fig. 3I). Each month, pigments were lowest at Fiesta Bay. At Ventura Point, pigment concentrations were generally higher during the day, while at Fiesta Bay, concentrations were generally high from $4 \mathrm{pm}$ to $4 \mathrm{am}$. At Hilton Dock, pigment concentrations were highest at night in July (Fig. 3C) and September (Fig. 3I).

Copepod adult, juvenile and nauplii density shifted from being highest in the back of the bay in July (Fig. 3C) to mid bay in August (Fig. 3E) and September (Fig. 3H). Densities were generally higher during the night for all locations. Densities were lowest at all sites in September (Figs. 3G, 3H, 3I). At Ventura Point and Fiesta Bay, copepod adult, juvenile and nauplii densities increased during ebb tides with the exception of September (Fiesta Bay). 
Densities decreased during the night ebb and increased during the night flood at Hilton Dock. Copepod adult, juvenile and nauplii densities generally tracked trends in temperature and salinity but were not clearly related to pigment concentration.

In July at Ventura Point, Acartia spp., Oithona similis, and Clausocalanus spp. densities were highest in the near-bottom samples at night, while Calanus helgolandicus densities were highest in the surface samples throughout the day (Appendix Figure 1). In August, Oithona similis, Calanus helgolandicus, and Clausocalanus spp. densities were highest in the near-bottom samples at night (Appendix Figure 2). At 6 am, a shift in densities was seen from the near-bottom to the surface in each of these taxa. In September, densities of Oithona similis, Calanus helgolandicus, and Clausocalanus spp. were highest in the near-bottom samples at night anddensities of Acartia spp. were highest in the last $8 \mathrm{pm}$ nearsurface sample (Appendix Figure 3). Across all three months at Ventura Point, copepod adult, juvenile and nauplii densities were elevated during low tides and consistently higher in the near-bottom samples compared to the surface samples. Another interesting pattern emerged when looking at species-specific density patterns. Each month at Ventura Point, Oithona similis and Clausocalanus spp. near-bottom and surface densities were low or zero through midday then noticeably higher in the $2 \mathrm{pm}$ sample.

At Fiesta Bay, Oithona similis and Clausocalanus spp. often had complementary vertical distributions. In July, Acartia spp. and Oithona similis tended to vary vertically, with surface densities peaking during the day and near- 
bottom densities peaking at night (Appendix Figure 4). However, unlike at Ventura Point, Clausocalanus spp. peaked at night in the near-bottom samples and were virtually absent throughout the day. In August, Clausocalanus spp. appeared to be the main component in near-bottom samples, while Oithona similis dominated surface samples (Appendix Figure 5). In September, densities decreased overall, and shifts in surface and near-bottom densities were mainly dominated by $O$. similis (Appendix Figure 6).

At Hilton Dock a completely different pattern was observed. In August, both Oithona similis and Clausocalanus spp. showed similar distribution patterns to Ventura Point. However, unlike at Ventura Point, surface densities were greatest at night (Appendix Figure 8). In September, the tides appeared to be closely correlated with both surface and near-bottom densities (Appendix Figure 9). 
Figure 3: Copepod and nauplii density (C), surface temperature (T), surface salinity (S), and surface photosynthetic pigments (P) during 24-hour sampling events at each site in each month. The left panels (A, D, G) show Ventura Point, the middle panels (B, E, H) show Fiesta Bay, and the right panels (C, F, I) show Hilton Dock. The left y-axis shows the temperature and salinity scale, while the right y-axis shows copepod and nauplii density and pigments. Night time is indicated by the gray shaded regions. High and low tides are indicated by the solid and dashed arrows, respectively. 


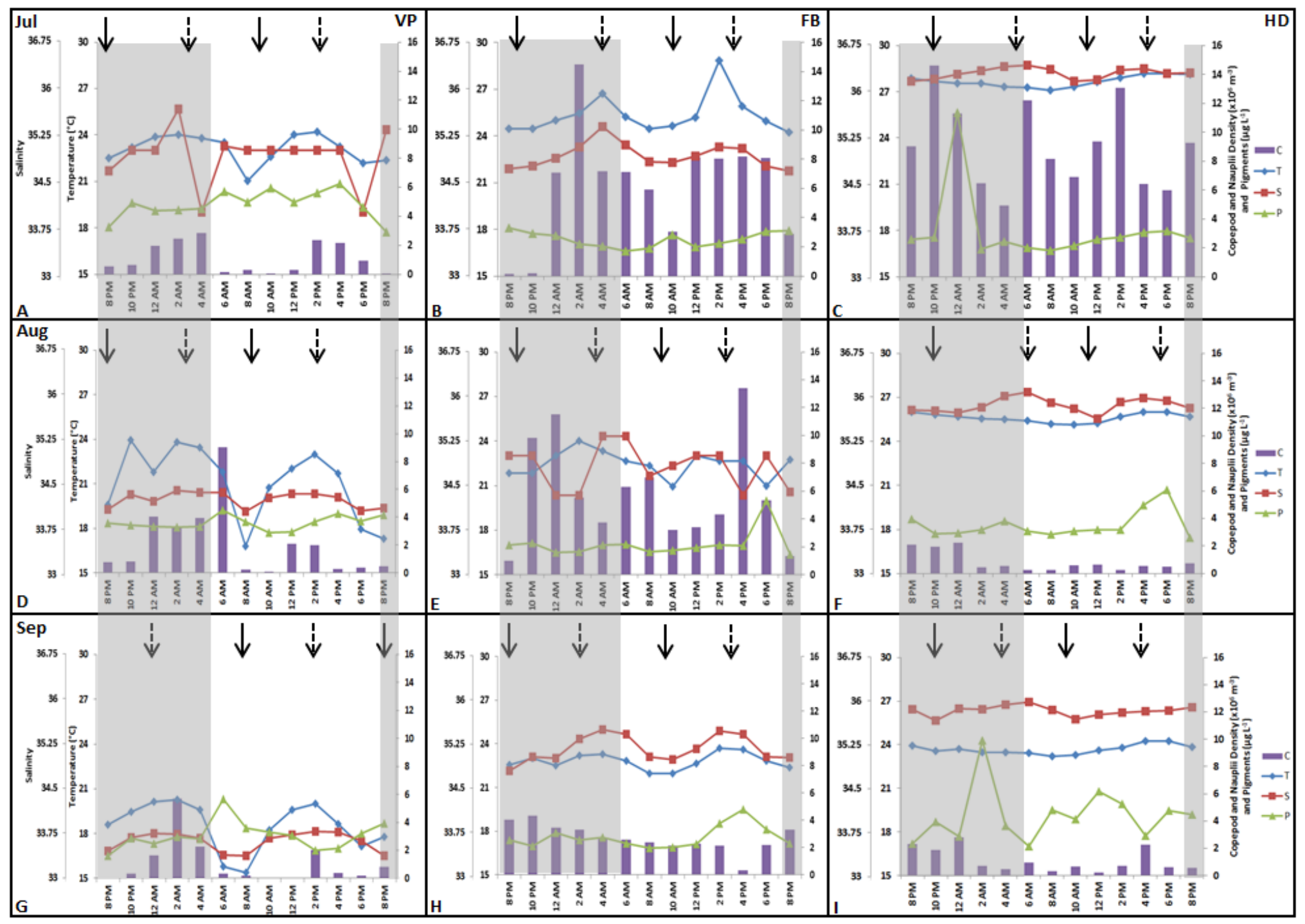


Table 6. Pearson's correlation coefficients for copepod and nauplius densities vs. tidal height. Asterisks represent p-values below three different thresholds. 


\begin{tabular}{|c|c|c|c|c|c|c|c|}
\hline \multirow[t]{2}{*}{ Location } & \multirow[t]{2}{*}{ Depth } & \multicolumn{2}{|c|}{ July } & \multicolumn{2}{|c|}{ August } & \multicolumn{2}{|c|}{ September } \\
\hline & & Copepods & $\underline{\text { Nauplii }}$ & $\underline{\text { Copepods }}$ & $\underline{\text { Nauplii }}$ & $\underline{\text { Copepods }}$ & $\underline{\text { Nauplii }}$ \\
\hline \multirow{4}{*}{$\begin{array}{l}\text { Ventura } \\
\text { Point }\end{array}$} & Surface & - & -0.10 & $-0.65^{*}$ & -0.19 & $-0.75 * * *$ & -0.25 \\
\hline & & $0.75 * * *$ & & & & & \\
\hline & Bottom & $-0.59 *$ & -0.12 & $-0.75 * * *$ & -0.10 & $-0.80 * * *$ & -0.51 \\
\hline & Surface & $-0.78 * * *$ & 0.36 & -0.20 & 0.46 & 0.50 & 0.28 \\
\hline \multirow{2}{*}{ Fiesta Bay } & Bottom & -0.49 & $0.61 *$ & -0.18 & 0.05 & 0.51 & $0.67 * *$ \\
\hline & Surface & 0.47 & -0.48 & $0.67 * *$ & 0.35 & 0.18 & -0.12 \\
\hline Hilton Dock & Bottom & $0.65^{*}$ & -0.38 & 0.25 & 0.35 & -0.30 & -0.34 \\
\hline
\end{tabular}


Tidal height correlated most strongly with copepod density at Ventura Point, with significant negative correlations between copepod density and tidal height in both the surface and near-bottom samples each month (Table 6). Overall, tidal height was not strongly correlated with densities of copepods and nauplii at Fiesta Bay, and showed a weak positive correlation with copepod densities at Hilton Dock. In July at Ventura Point and Fiesta Bay, surface copepod densities were significantly negatively correlated with tidal height, while at Hilton Dock near-bottom copepod density was positively correlated with tidal height. In August, a negative correlation between copepod density and tidal height again was observed at Ventura Point, and surface copepod density at Hilton Dock was positively correlated with tidal height. In September, copepod density again was negatively correlated with tidal height at Ventura Point. At Ventura Point in July, the negative copepod density correlation was strongest in the near-surface sample while in August and September the negative correlations were strongest in the near-bottom samples. The only strong correlations for nauplii were positive correlations with tidal height observed solely in the near-bottom samples at Fiesta Bay in July and September.

Statistical relationships between temperature, salinity, pigments, and densities of copepod adult, juvenile and nauplii were examined with Pearson's correlations (Table 7). At Ventura Point, temperature and salinity were strongly positively correlated in August and September (Table 7A) $(R \geq 0.78)$. In September, temperature and salinity were strongly negatively correlated with pigment concentrations $(\mathrm{R}=-0.53, \mathrm{R}=-0.50$, respectively). Temperature was 
strongly positively correlated with copepod density during each month $(\mathrm{R} \geq 0.53)$. Salinity was negatively correlated with copepod densities in July $(\mathrm{R}=-0.42)$ and positively correlated with copepod densities in August $(\mathrm{R}=0.57)$. Pigments were not strongly correlated with copepod adult, juvenile and nauplii densities at Ventura Point.

At Fiesta Bay (Table 7B), temperature and salinity were strongly positively correlated in July $(\mathrm{R}=0.73)$ and September $(\mathrm{R}=0.88)$. Pigment concentration was negatively correlated with salinity in July $(R=-0.41)$ and with temperature in August $(\mathrm{R}=-0.55)$. Temperature was negatively correlated with densities of nauplii in July $(\mathrm{R}=-0.44)$ and both nauplii and copepods in September $(R=-0.50, R=-0.49)$. Salinity was also negatively correlated with densities of nauplii in July $(\mathrm{R}=-0.56)$ and both copepods and nauplii in September $(\mathrm{R}=-0.44, \mathrm{R}=-0.64)$, but positively correlated with copepod densities in July $(\mathrm{R}=0.46)$. Pigment concentration was strongly positively correlated with densities of nauplii in July $(\mathrm{R}=0.51)$ and negatively correlated with copepod densities in September $(\mathrm{R}=-0.21)$.

At Hilton Dock, there were very few strong correlations each month, and none in July (Table 7C). In August, temperature and pigment concentration were positively correlated $(\mathrm{R}=0.49)$ while salinity was negatively correlated with copepod density $(\mathrm{R}=-0.55)$. In September, temperature was positively correlated with densities of copepods and nauplii ( $R=0.45, R=0.43$, respectively). 
Table 7. Pearson's correlations between hydrographic parameters (temperature, salinity), pigments, and densities of copepods and nauplii at each site. Values above the gray cells are correlation coefficients $(\mathrm{R})$, and values below the gray cells are p-values. $\mathrm{N}=26$ for each correlation. 


\begin{tabular}{|c|c|c|c|c|c|}
\hline $\begin{array}{l}\text { A } \\
\text { Jul VP } \\
\end{array}$ & $\underline{\text { Temp }}$ & $\underline{\text { Salinity }}$ & $\underline{\text { Pigments }}$ & $\underline{\text { Copepods }}$ & $\underline{\text { Nauplii }}$ \\
\hline Temperature & & -0.12 & 0.03 & 0.53 & 0.14 \\
\hline Salinity & 0.56 & & -0.27 & -0.42 & -0.20 \\
\hline Pigments & 0.88 & 0.19 & & 0.26 & 0.24 \\
\hline$\overline{\text { Copepods }}$ & 0.005 & 0.03 & 0.20 & & 0.47 \\
\hline Nauplii & 0.50 & 0.32 & 0.23 & 0.02 & \\
\hline Aug VP & Temp & Salinity & Pigments & Copepods & Nauplii \\
\hline$\overline{\text { Temp }}$ & & 0.95 & -0.34 & 0.58 & 0.23 \\
\hline Salinity & $<0.001$ & & -0.25 & 0.57 & 0.35 \\
\hline Pigments & 0.09 & 0.23 & & -0.15 & -0.15 \\
\hline$\overline{\text { Copepods }}$ & 0.002 & 0.002 & 0.45 & & 0.26 \\
\hline Nauplii & 0.26 & 0.09 & 0.45 & 0.20 & \\
\hline$\underline{\text { Sep VP }}$ & $\underline{\text { Temperature }}$ & $\underline{\text { Salinity }}$ & Pigments & Copepods & Nauplii \\
\hline Temperature & & 0.78 & -0.53 & 0.57 & 0.44 \\
\hline Salinity & $<0.001$ & & -0.50 & 0.37 & 0.22 \\
\hline Pigments & 0.005 & 0.009 & & 0.02 & -0.08 \\
\hline$\overline{\text { Copepods }}$ & 0.002 & 0.06 & 0.93 & & 0.64 \\
\hline Nauplii & 0.03 & 0.28 & 0.71 & $<0.001$ & \\
\hline
\end{tabular}

\begin{tabular}{|c|c|c|c|c|c|}
\hline $\begin{array}{l}\text { Bul FB } \\
\text { Jul }\end{array}$ & Temp & Salinity & Pigments & Copepods & $\underline{\text { Nauplii }}$ \\
\hline Temperature & & 0.73 & -0.26 & 0.35 & -0.44 \\
\hline Salinity & $<0.001$ & & -0.41 & 0.46 & -0.56 \\
\hline Pigments & 0.19 & 0.04 & & -0.34 & 0.51 \\
\hline Copepods & 0.07 & 0.02 & 0.09 & & -0.21 \\
\hline Nauplii & 0.03 & 0.003 & 0.007 & 0.31 & \\
\hline$\underline{\text { Aug FB }}$ & $\underline{\text { Temp }}$ & $\underline{\text { Salinity }}$ & $\underline{\text { Pigments }}$ & $\underline{\text { Copepods }}$ & $\underline{\text { Nauplii }}$ \\
\hline$\overline{\text { Temp }}$ & & -.004 & -0.55 & -0.38 & -0.12 \\
\hline Salinity & 0.98 & & 0.13 & -0.31 & -0.24 \\
\hline Pigments & 0.003 & 0.52 & & 0.18 & -0.05 \\
\hline$\overline{\text { Copepods }}$ & 0.06 & 0.12 & 0.37 & & -0.03 \\
\hline Nauplii & 0.54 & 0.23 & 0.81 & 0.89 & \\
\hline$\underline{\text { Sep FB }}$ & $\underline{\text { Temperature }}$ & $\underline{\text { Salinity }}$ & $\underline{\text { Pigments }}$ & $\underline{\text { Copepods }}$ & $\underline{\text { Nauplii }}$ \\
\hline Temperature & & 0.88 & 0.22 & -0.49 & -0.50 \\
\hline Salinity & $<0.001$ & & 0.22 & -0.44 & -0.64 \\
\hline Pigments & 0.29 & 0.29 & & -0.43 & -0.21 \\
\hline Copepods & 0.01 & 0.03 & 0.03 & & 0.50 \\
\hline Nauplii & 0.01 & $<0.001$ & 0.31 & 0.01 & \\
\hline
\end{tabular}




\begin{tabular}{|c|c|c|c|c|c|}
\hline $\begin{array}{l}\text { C } \\
\text { Jul HD }\end{array}$ & Temp & Salinity & Pigments & Copepods & $\underline{\text { Nauplii }}$ \\
\hline Temperature & & -0.20 & 0.15 & 0.30 & -0.36 \\
\hline Salinity & 0.33 & & -0.24 & -0.35 & 0.14 \\
\hline Pigments & 0.47 & 0.24 & & 0.27 & -0.05 \\
\hline Copepods & 0.14 & 0.08 & 0.19 & & -0.11 \\
\hline Nauplii & 0.07 & 0.48 & 0.81 & 0.59 & \\
\hline$\underline{\text { Aug HD }}$ & Temp & Salinity & Pigments & Copepods & Nauplii \\
\hline Temp & & -0.05 & 0.49 & 0.35 & 0.29 \\
\hline Salinity & 0.79 & & 0.19 & -0.55 & -0.29 \\
\hline Pigments & 0.01 & 0.34 & & 0.25 & 0.13 \\
\hline Copepods & 0.08 & 0.004 & 0.23 & & 0.68 \\
\hline Nauplii & 0.15 & 0.15 & 0.53 & $<0.001$ & \\
\hline$\underline{\operatorname{Sep} H D}$ & $\underline{\text { Temperature }}$ & Salinity & $\underline{\text { Pigments }}$ & Copepods & $\underline{\text { Nauplii }}$ \\
\hline$\overline{\text { Temperature }}$ & & 0.06 & -0.27 & 0.45 & 0.43 \\
\hline Salinity & 0.79 & & 0.04 & 0.04 & -0.06 \\
\hline Pigments & 0.19 & 0.85 & & -0.20 & -0.13 \\
\hline Copepods & 0.02 & 0.86 & 0.34 & & 0.56 \\
\hline Nauplii & 0.03 & 0.76 & 0.52 & 0.003 & \\
\hline
\end{tabular}




\subsection{DISCUSSION}

In the past, two surface copepod studies have been completed in Mission Bay; however, these studies were conducted by towing a $53 \mu \mathrm{m}$ mesh net with a $0.5 \mathrm{~m}$ diameter ring (Kittinger 2006, Elliott 2006). In both studies, the most abundant copepod species throughout the bay was Oithona similis, which was generally about ten times more abundant than the second most abundant species, Acartia californiensis. In this current study, Oithona similis was also the most abundant species; however, A. californiensis was never observed. The disappearance of A. californiensis could be in part due to the different sampling methods and pump avoidance compared to net avoidance. Copepods that are considered active swimmers have been known to avoid capture by both nets and pumps (Fleminger and Clutter 1965, McGowan and Fraundorf 1966, Matthew 1988, Ianson et al. 2004, Masson et al. 2004); however, it has been observed that active swimming copepods are generally better represented in net tows when compared to pump samples (Masson et al. 2004). Additionally, the larger the diameter of the net or the intake of the pump, the easier it is to capture active swimming copepods (Fleminger and Clutter 1965, McGowan and Fraundorf 1966, Liu et al. 2009). The diameter of the net used in the previous Mission Bay studies (Elliott 2006, Kittinger 2006) was about 1.5x the size of the pump intake used in this study, which could explain why A. californiensis was so abundant in previous studies but absent from the samples described here. Therefore, is very possible that A. californiensis was present in the bay during this current study, but actively avoided the intake of the pump. 
Both Kittinger (2006) and Elliott (2006) found a spatial pattern in total density throughout the bay, with greatest surface densities in the back bay and lowest surface densities in the front bay in the summer. In 2001-2002, front bay densities were highest in August, while mid and back bay densities were highest in July and decreased through September (Kittinger 2006). The copepod densities observed in both of these studies were an order of magnitude lower than the densities observed in the current study, though, as previously noted, the methods used in the current study differed in a number of respects: this study used a pump system rather than a towed net; used a $100 \mu \mathrm{m}$ mesh net instead of a $53 \mu \mathrm{m}$ mesh net; filtered a smaller volume of water per sample $\left(\sim 2 \mathrm{~m}^{3}\right.$ versus $\left.20-23 \mathrm{~m}^{3}\right)$; included sampling over a 24-hour period instead of just sampling during the day; involved monthly sampling instead of biweekly sampling; and collected more samples per sampling event (26 versus 1). Additionally, during July-September, the bay in both the previous studies was more saline at each site than in this study. Temperature, however, was slightly warmer in this study.

Cooler, less saline waters were observed in the front and mid bay and were likely due to tidal mixing, which becomes increasingly weak with distance from the ocean (Largier et al. 1997, 2003). The warmer, more saline waters at Hilton Dock were likely a result of limited tidal flushing and long residence times due to the location of the site, high evaporation, and reduced freshwater input from streams or runoff (Largier et al. 1997, 2003). At Ventura Point and Fiesta Bay, temperature and salinity were generally positively correlated with one another, while this relationship was not observed at Hilton Dock. In a previous study, no 
correlation was observed between temperature and salinity in the front and mid bay, while in the back bay a strong positive correlation was observed (Swope 2005). However, it is important to note that the data set analyzed by Swope (2005) covered a complete year, compared to the three month period covered in this study. Largier et al. $(1997,2003)$ found that temperature reached a relatively stable maximum farther into the estuary, whereas salinity kept increasing. Similar spatial patterns for temperature and salinity in the bay have been observed previously (Swope 2005, Elliott and Kaufmann 2007, Griggs 2009).

In previous studies, densities of both copepods and nauplii were strongly positively correlated with salinity in the back bay (Elliott 2006). In the mid bay, copepod densities were strongly positively correlated with temperature, while densities of nauplii were strongly positively correlated with both temperature and salinity. In the front bay, densities of nauplii were strongly positively correlated with temperature. Kittinger (2006) found that much of the zooplankton variation in the back and mid bay was explained by variation in temperature and salinity, in addition to phosphate concentration, Secchi disk depth, silica concentration, tidal magnitude, day length, and amount of precipitation. In addition, tidal magnitude was negatively correlated with temperature and salinity at each site.

In this current study, spatial trends in copepod and nauplii densities differed from previous studies and throughout each day of the study period. When copepod and nauplius densities were low in surface samples, densities did not increase in the near-bottom sample collected two hours later, suggesting that a large proportion of the copepods resided below the surface sampling depth, or 
copepods moved horizontally with the tide and were no longer at the sampling site. Throughout the study at Ventura Point, Oithona similis, Calanus helgolandicus, and Clausocalanus spp. densities tended to be greater in the nearbottom sample during ebb tide, especially during the night ebb. During the night ebb, the peak in densities lasted about 6 hours, while the peak around the $2 \mathrm{pm}$ ebb tide was less prolonged and only lasted about 2 hours. This pattern in elevated densities during ebb tides could be due to the relationship between tidal and diel influences on copepod migration in the front bay in addition to food distribution.

Oithona similis is a very common omnivorous species found throughout both hemispheres in oceans and estuaries (Fish 1936, Hansen et al. 2004, Castellani et al. 2005, Dvoretsky and Dvoretsky 2009, Zamora-Terol et al. 2014, Cepeda et al. 2015). This species has been reported to migrate vertically on a diel basis in some locations but not in others. Oithona similis showed consistent vertical distributions throughout a stratified water column in the Baltic Sea (Hansen et al. 2004) and throughout the year in the South China Sea (Hwang et al. 2010). In the Southern Ocean, O. similis were near the ocean surface in greater abundance at night than during the day, suggesting diel vertical migration north of about $65{ }^{\circ} \mathrm{S}$ but not south of this latitude (Pinkerton et al. 2010). Elsewhere in the Antarctic, diel vertical migration by $O$. similis was observed on a limited basis (Tanimura et al. 2008), and in the Arctic, Fortier et al. (2001) reported little vertical migration. Limited diel variation throughout the water column was attributed to the descent of food sources deeper in the water column (Tanimura et al. 2008) and the wide distribution of food sources (Fortier et al. 2001). A very 
similar species, $O$. plumifera, has been studied in the Mondego estuary (Portugal), a mesotidal estuary somewhat deeper than Mission Bay (Gonçalves et al. 2012). In this location, this species was relatively evenly distributed between samples collected near the surface and the estuary floor during summer spring tides (Gonçalves et al. 2012). Oithona similis has also been observed remaining within or below the pycnocline (Lischka and Hagen 2005, Maar et al. 2006), and densities have not been significantly correlated with temperature and salinity (Hwang et al. 2010). In addition, $O$. similis has been reported to reside below the zone of primary production, likely due to its omnivorous nature (Sameoto 1984).

Within Mission Bay, a relatively shallow estuary, $O$. similis did not seem to migrate solely on a diel cycle. Rather, it was found throughout the water column and predominated in the lower portion of the water column during ebb tide, especially at night. This distribution of copepods may have been related to the distribution of their food, as reported in previous studies (Fortier et al. 2001, Tanimura et al. 2008).

In the North Atlantic, the predominant food source for $O$. similis was ciliates (Castellani et al. 2005). In fact, clearance rates for $O$. similis feeding on ciliates were higher than those feeding on phytoplankton, and thus $O$. similis were selectively feeding on ciliates (Castellani et al. 2005). However, when ciliate densities were low, $O$. similis fed on other available nano- and microplankton. In Australia, $O$. similis also preferentially fed on ciliates in addition to other flagellates (Zamora-Terol et al. 2014). Although densities of ciliates and phytoplankton were not measured in this study, a proxy measure for 
phytoplankton (photosynthetic pigment concentrations) was relatively evenly distributed throughout the water column, perhaps affecting the distribution of $O$. similis.

In a previous study in Mission Bay (Swope 2005), diatoms generally dominated the phytoplankton community throughout the summer. In the front bay, rapid transitions between diatom blooms and subsequent dinoflagellate blooms occurred, though these were less pronounced in the mid bay. In the back bay, the summer months were dominated solely by diatoms. In addition, the diatoms in the front bay were more diverse and of more coastal origin, whereas the species in the mid and back bay were of more estuarine origin with decreasing diversity (Swope 2005). Strong negative relationships between salinity and dinoflagellate abundance have been observed (Swope 2005), while strong positive relationships between temperature and dinoflagellate abundance have been observed (Elliott and Kaufmann 2007). It is possible that the significant correlations in this study could be due to a shift in phytoplankton community composition between diatoms and dinoflagellates.

Throughout the study, weak relationships were observed between copepod densities and photosynthetic pigment concentrations. This is likely because the prevalent species (Oithona similis, Clausocalanus spp., and Acartia spp.) are omnivores (Sameoto 1984, Kleppel 1993). When looking at mean species diversity, evenness and richness throughout Mission Bay, an interesting pattern emerged. Values for all three indices were highest in the front bay and decreased with increasing distance from the mouth. In addition, more neritic species were 
observed in the front bay, while more estuarine species were observed in the back bay. This pattern suggests that the front of the bay may be more diverse because of the oceanic influence. Similar results were observed by Elliott and Kaufmann (2007), and Swope (2005).

While food distribution may be a driving force for Oithona similis vertical distribution in Mission Bay, it is not clear why $O$. similis densities were highest in near-bottom samples at night in the front bay. It is possible that this species acts completely differently in areas with higher tidal influence. The mid and back bay were less affected by tides and had consistently higher salinities and temperatures. This could account for the lack of vertical variation in $O$. similis distributions throughout the day, because $O$. similis generally is found in areas of high salinity (Lischka and Hagen 2005, Maar et al. 2006). The distribution of $O$. similis could also be related to tidal cycles. As the surface temperature increased at Ventura Point and tidal height decreased, copepod densities increased. This is likely because, during ebb tide, warmer back bay water was being pulled toward the mouth of the bay, transporting copepods as well.

While this migration was observed in the front bay, it was not observed at any of the other sites, suggesting a strong ocean influence in the front bay. Unlike the results from previous studies in estuaries (Kimmerer et al. 1987, Hough and Naylor 1991, Kimmerer et al. 1998, Kimmerer et al. 2002, Kimmerer et al. 2014), tidal vertical migration was not observed throughout the entire bay. This could be due to the shallower depth and gradient of tidal influence within Mission Bay compared to those of other bays where similar research has been conducted. 
Another possibility is that vertical migration throughout the bay only occurs when the water column is stratified. Stratification has been reported in previous studies on Mission Bay (Swope 2005, Elliott 2006, Kittinger 2006, Elliott and Kaufmann 2007, Griggs 2009) but was not observed in this study. To further investigate this possibility and to understand if diel vertical migration takes place within the bay, sampling should be conducted during multiple seasons, including a dry and a wet season (specifically after rain events), so that the water column would be well mixed in one season and stratified in another. Sampling also could be carried out during both spring and neap tides to better understand the impact of tidal range on copepod migratory behavior. Additionally, if sampling took place during the same months as this study to include both the full moon spring tide and the new moon spring tide, the effect of light intensity on copepod vertical distribution could be examined. 


\subsection{REFERENCES}

Antacli, J.C., D. Hernández, and M.E. Sabatini. 2010. Estimating copepods' abundance with paired nets: Implications of mesh size for population studies. Journal of Sea Research 63: 71-77.

Bollens, S. M., G. Rollwagen-Bollens, J. A. Quenette, and A. B. Bochdansky. 2010. Cascading migrations and implications for vertical fluxes in pelagic ecosystems. Journal of Plankton Research 33(3): 349-355.

Castellani C., X. Irigoien, R.P. Harris, and R.S. Lampitt. 2005. Feeding and egg production of Oithona similis in the North Atlantic. Marine Ecology Progress Series 288: 173-182.

Chew L. L., Chong V. C., Ooi A. I., Sasekumar A. 2015. Vertical migration and positioning behavior of copepods in a mangrove estuary: interactions between tidal, diel light and lunar cycles. Estuarine, Coastal and Shelf Science 152: 142152.

Day, J.W., B.C. Crump, W.M. Kemp, and A. Yáñez-Arancibia, 2013. Estuarine Ecology, second edition. Wiley-Blackwell, New Jersey.

Devreker, D., S. Souissi, J.C. Molinero, and F. Knubito. 2008. Trade-offs of the copepod Eurytemora affinis in mega-tidal estuaries: insights from high frequency sampling in the Seine estuary. Journal of Plankton Research 30(12): 1329-1342.

Durham, W.M., and R. Stocker. 2012. Thin phytoplankton layers: characteristics, mechanisms, and consequences. Annual Review of Marine Science 4: 177-207.

Dvoretsky, V.G. and A.G. Dvoretsky. 2009. Life cycle of Oithona similis (Copepoda: Cyclopoida) in Kola Bay (Barents Sea). Marine Biology 156(7): 1433-1446.

Elliott, D.T. 2006. Environmental Factors Affecting the Zooplankton Community in Mission, Bay, San Diego, California. M.S. Thesis, University of San Diego.

Elliott, D.T. and R.S. Kaufmann, 2007. Spatial and temporal variability of copepod adult, juvenile and nauplii and tintinnid ciliates in a seasonally hypersaline estuary. Estuaries and Coasts 30(3): 418-430.

Evans, M.S. and D.W. Sell, 1985. Mesh size and collection characteristics of 50cm diameter conical plankton nets. Hydrobiologica 122: 97-104.

Fish, C.J., 1936. The biology of Oithona similis in the Gulf of Maine and Bay of Fundy. The Biological Bulletin 71(1): 168-187. 
Fleminger, A. and R.I. Clutter, 1965. Avoidance of towed nets by zooplankton. Limnology and Oceanography 10(1): 96-104.

Fortier, M., L. Fortier, H. Hattori, H. Saito, H. and L. Legendre. 2001. Visual predators and the diel vertical migration of copepods under Arctic sea ice during the midnight sun. Journal of Plankton Research 23(11): 1263-1278.

Gonçalves, A.M.M., M.A. Pardal, S.C. Marques, S. Mendes, M.J. FernándezGómez, M.P. Galindo-Villardón, and U.M. Azeiteiro. 2012. Diel vertical behavior of Copepoda community (naupliar, copepodites and adults) at the boundary of a temperate estuary and coastal water. Estuarine, Coastal and Shelf Science 98: 1630 .

Griggs, R.B. 2009. Temporal and Spatial Dynamics of the Meroplankton Assemblage in Mission Bay, San Diego, California. M.S. Thesis, University of San Diego.

Hays, G.C., C.A. Proctor, A.W.G. John, and A.J. Warner. 1994. Interspecific differences in the diel vertical migration of marine copepods: The implications of size, color, and morphology. Limnology and Oceanography 39(7): 1621-1629.

Hansen, F.C., C. Möllmann, U. Schütz, and H.H. Hinrichsen. 2004. Spatiotemporal distribution of Oithona similis in the Bornholm Basin (central Baltic Sea). Journal of Plankton Research 26(6): 659-668.

Holm-Hansen, O., C.J. Lorenzen, R.W. Holmes, J.D.H. Strickland. 1965. Fluorometric Determination of Chlorophyll. ICES Journal of Marine Science 30(1): 3-15.

Hough, A.R. and E. Naylor, 1991. Field studies on retention of the planktonic copepod Eurytemora affinis in a mixed estuary. Marine Ecology Progress Series 76: $115-122$.

Hwang, J.S., R. Kumar, H.U. Dahms, L.C. Tseng, and Q.C. Chen. 2010. Interannual, seasonal, and diurnal variation in vertical and horizontal distribution patterns of 6 Oithona spp.(Copepoda: Cyclopoida) in the South China Sea. Zoological Studies 49(2): 220-229.

Ianson, D., G.A. Jackson, M.V. Angel, R.S. Lampitt, and A.B. Burd. Effect of net avoidance on estimates of diel vertical migration. Limnology and Oceanography 49(6): 2297-2303.

Intxausti, L., F. Villate, I. Uriarte, A. Iriarte, and I. Ameztoy. 2012. Size-related response of zooplankton to hydroclimatic variability and water-quality in an organically polluted estuary of the Basque coast (Bay of Biscay). Journal of Marine Systems 94: 87-96. 
Kaufmann, R.S., B.C. Stransky, J. Rudolph, D.T. Elliott, R.B. Griggs, J.N. Kittinger, B.L. Swope, J.P. Bolender, M.A. Boudrias and H.A. Sarabia. 2004. Mission Bay Water and Sediment Testing Project, Final Report. City of San Diego, 101 pp.

Kimmerer, W.J., J.R. Burau, and W.A. Bennett. 1998. Tidally oriented vertical migration and position maintenance of zooplankton in a temperate estuary.

Limnology and Oceanography 43(7): 1697-1709.

Kimmerer, W.J. and A.D. McKinnon, 1987. Zooplankton in a marine bay. II. Vertical migration to maintain horizontal distributions. Marine Ecology Progress Series 41: 53-60.

Kimmerer, W.J. 1993. Distribution patterns of zooplankton in Tomales Bay, California. Estuaries 16(2): 264-272.

Kimmerer, W.J., J.R. Burau, and W.A. Bennett. 2002. Persistence of tidallyoriented vertical migration by zooplankton in a temperate estuary. Estuaries 25(3): 359-371.

Kimmerer W.J., E.S. Gross, and M.L. MacWilliams. 2014. Tidal migration and retention of estuary zooplankton investigated using a particle-tracking model. Limnology and Oceanography 59(3): 901-916.

Kittinger, J.N. 2006. Aspects of estuarine copepod adult, juvenile and nauplii dynamics in Mission Bay, San Diego, CA. M.S. Thesis, University of San Diego.

Kleppel, G.S. 1993. On the diets of calanoid copepods. Marine Ecology Progress Series 99: 183-195.

Lampert, W. 1989. The adaptive significance of diel vertical migration of zooplankton. Functional Ecology 3: 21-27.

Landry M.R. and R.P. Hassett, 1982. Estimating the grazing impact of marine micro-zooplankton. Marine Biology 67: 283-288.

Landry M.R., S.L. Brown, L. Campbell, J. Constantinou, and H. Liu. 1998. Spatial patterns in phytoplankton growth and microzooplankton grazing in the Arabian Sea during monsoon forcing. Deep Sea Research Part II: Topical Studies in Oceanography 45(10-11): 2353-2368.

Laprise, R. and J.J. Dodson, 1994. Environmental variability as a factor controlling spatial patterns in distribution and species diversity of zooplankton in the St. Lawrence Estuary. Marine Ecology Progress Series 107: 67-81.

Largier, J.L., M. Carter, M. Roughan, D. Suttin, J. Helly, B. Lesh, T. Kacena, P. Ajtai, L. Clarke, D. Lucas, P. Walsh, and L. Carillo. 2003. Mission Bay Contaminant Dispersion Study Final Report. City of San Diego. 77 pp. 
Largier, J.L., J.T. Hollibaugh, and S.V. Smith. 1997. Seasonally hypersaline estuaries in Mediterranean-climate regions. Estuarine, Coastal and Shelf Science 45: 789-797.

Lischka, S. And W. Hagen. 2005. Life histories of the copepods Pseudocalanus minutus, P. acuspes (Calanoida) and Oithona similis (Cyclopoida) in the Arctic Kongsfjorden (Svalbard). Polar Biology 28(12): 910-921.

Lorenzen, C.J.1966. A method for the continuous measurement of in vivo chlorophyll concentration. Deep Sea Research and Oceanographic Abstracts 13(2): 223-227.

Lougee, L.A., S.M. Bollens, S.R. Avent. 2002. The effects of haloclines on the vertical distribution and migration of zooplankton. Journal of Experimental Marine Biology and Ecology 278: 111-134.

Maar, M., A.W. Visser, T.G. Nielsen, A. Stips, and H. Saito. 2006. Turbulence and feeding behaviour affect the vertical distributions of Oithona similis and Microsetella norwegica. Marine Ecology Progress Series 313: 157-172.

Marques, S.C., U.M. Azeiteiro, J.C. Marques, J.M. Neto, and M.Â. Pardal. 2006. Zooplankton and ichthyoplankton communities in a temperate estuary: spatial and temporal patterns. Journal of Plankton Research 28(3): 297-312.

Marques, S.C., M.A. Pardal, M.J. Pereira, F. Gonçalves, J.C Marques, and U.M. Azeiteiro. 2007. Zooplankton distribution and dynamics in a temperate shallow estuary. Hydrobiologica 587: 213-223.

Masson, S., B. Pinel-Alloul, G. Méthot, and N. Richard. 2004. Comparison of nets and pump sampling gears to assess zooplankton vertical distribution in stratified lakes. Journal of Plankton Research 26(10): 1199-1206.

Matthew, K.J. 1988. Net avoidance behaviour among larval, juvenile, and adult euphausiids. Journal of the Marine Biological Association of India 30(1\&2): 9398.

McGowan, J.A. and V.J. Fraundorf. 1966. The relationship between size of net used and estimates of zooplankton diversity. Limnology and Oceanography 11(4): 456-469.

Morgan, C.A., J.R. Cordell, C.A. Simenstad. 1997. Sink or swim? Copepod population maintenance in the Columbia River estuarine turbidity-maxima region. Marine Biology 129: 309-317.

Pinkerton, M.H., A.N. Smith, B. Raymond, G.W. Hosie, B. Sharp, J.R. Leathwick, and J.M. Bradford-Grieve. 2010. Spatial and seasonal distribution of adult Oithona similis in the Southern Ocean: predictions using boosted regression trees. Deep Sea Research Part I: Oceanographic Research Papers 57(4): 469-485. 
Primo, A.L, U.M. Azeiteiro, S.C. Marques, F. Martinho, and M.Â. Paradal. 2009. Changes in zooplankton diversity and distribution pattern under varying precipitation regimes in a southern temperate estuary. Estuarine, Coastal and Shelf Science 82: 341-347.

Rawlinson, K.A., J. Davinport, and D.K.A. Barnes. 2004. Vertical migration strategies with respect to advection and stratification in a semi-enclosed lough: a comparison of mero- and holozooplankton. Marine Biology 144: 935-946.

Sameoto D.D. 1984. Vertical distribution of zooplankton biomass and species in northeastern Baffin Bay related to temperature and salinity. Polar Biology 2: 213224.

Stoecker D.K. and J.M. Capuzzo, 1990. Predation on Protozoa: its importance to zooplankton. Journal of Plankton Research 12(5): 891-901.

Strom, S.L., M.A. Brainard, J.L. Holmes, and M.B. Olson. 2001. Phytoplankton blooms are strongly impacted by microzooplankton grazing in coastal North Pacific waters. Marine Biology 138: 355-368.

Swope, B. 2005. Spatial and temporal dynamics of phytoplankton in Mission Bay over a complete annual cycle. M.S. Thesis, University of San Diego.

Tanimura, A., H. Hattori, Y. Miyamoto, T. Hoshiai, T. and M. Fukuchi. 2008. Diel changes in vertical distribution of Oithona similis (Cyclopoida) and Oncaea curvata (Poecilostomatoida) under sea ice in mid-summer near Syowa Station, Antarctica. Polar Biology 31(5): 561-567.

Tseng, L., H. Dahms, J. Hung, Q. Chen, J. Hwang. 2011. Can different mesh sizes affect the results of copepod community studies? Journal of Experimental Marine Biology and Ecology 398: 47-55.

Ueda H., M. Kuwatani, and K.W. Suzuki. 2010. Tidal vertical migration of two estuarine copepods: naupliar migration and position-dependent migration. Journal of Plankton Research 32(11): 1557-1572.

Vieira, L., U. Azeiteiro, P. Ré, R. Pastorinho, J.C. Marques, and F. Morgado. 2003. Zooplankton distribution in a temperate estuary (Mondego estuary southern arm: Western Portugal). Acta Oecologica 24: S163-S173.

Vineetha G., R. Jyothibabu, n.V. Madhu, K.K. Kusum, P.M. Sooria, A. Shivaprasad, P.D. Reny, and M.P. Deepak. 2015. Tidal influence on the diel vertical migration pattern of zooplankton in a tropical monsoonal estuary. Wetlands 356(3): 597-610.

Wooldridge, T. and T. Erasmus, 1980. Utilization of tidal currents by estuarine zooplankton. Estuarine and Coastal Marine Science 11: 107-114. 
Xu, S., W. Guizhong, L. Shaojing, G. Donghui. 2007. Preliminary study of the retention mechanism of planktonic copepods in the Jiulong Estuary in China. Acta Oceanologica Sinica 26(4): 156-163.

Zamora-Terol S., A.D. Mckinnon, and E. Saiz. 2014. Feeding and egg production of Oithona spp. in tropical waters of North Queensland, Australia. Journal of Plankton Research 36(4): 1047-1059. 


\section{CHAPTER 3: GENERAL THESIS CONCLUSION}

Throughout this study, variations between the three sample sites within Mission Bay were evident, and there was a clear effect of tidal influence on the copepod community and hydrographic parameters throughout the bay. Consistent patterns were observed, with copepod adult, juvenile and nauplii diversity, taxonomic richness, and evenness being highest, while temperature and salinity were lowest in the front bay. As diversity, richness, and evenness decreased with increasing distance into the bay, temperature and salinity also increased with distance from the mouth.

The results of this research about tidal flow and its influence on communities throughout Mission Bay could apply more broadly to include particle flow, zooplankton communities in general, larval dispersal, and other mesotidal Mediterranean climate estuaries. Previous research on the dynamics of passive versus active particles in an estuary has shown that passive particles tend to be advected from an estuary whereas actively migrating particles are generally retained (Kimmerer et al. 2014). However, Kimmerer et al. (2014) speculated that the actively migrating particles may have been retained in the estuary due to their interaction with bathymetric features. In Mission Bay, copepods in the front bay were actively migrating with the tide, suggesting that they were likely to be retained within the estuary. However, in the back bay, copepods seemed to be more passive, increasing in abundance with the rising tides and decreasing in abundance with the ebbing tides, thus potentially being advected toward the front bay. This suggests that within Mission Bay there is a spatial dichotomy between 
active and passive particles interacting with the tides. Kimmerer et al. (2014) treated all copepods within in estuary as either active or passive particles. The results of this study suggest that both types of behaviors can be present within a species, depending on hydrographic conditions in a particular region of Mission Bay.

The influence of tidal flow can also be applied to larval dispersal and broader zooplankton communities. The tidal information gleaned from this research could be very helpful in predicting where the greatest densities of larvae can be found. One would expect to see an overall greater diversity in both larval and zooplankton communities (not just copepods) in the front bay. With the great diversity in the lower levels of the food chain observed in the front bay, one could also theorize that overall species density would be higher in the front bay.

This research may also be applied to other Mediterranean climate estuaries as a baseline. There are relatively few published studies on Mediterranean climate estuaries, and consequently there are very few studies on copepods within those estuaries. This research could help in understanding overall density trends observed in these estuaries. Also, very few studies have been conducted with such high temporal resolution. Previous research in these estuaries, including Mission Bay, may have misidentified certain density trends due to a lack of samples. Future research in Mission Bay should be conducted with sufficiently high resolution to properly address the questions being posed. 


\section{CHAPTER 4: APPENDIX}

Figure 1. Copepod density vs. time at Ventura Point in July. Blue lines with diamonds indicate near-surface (Sf) densities. Red lines with squares indicate 0.5 m above bottom (Bt) densities. A: Acartia clausi and Acartia tonsa, B: Oithona similis, C: Calanus helgolandicus, D: Clausocalanus spp. 

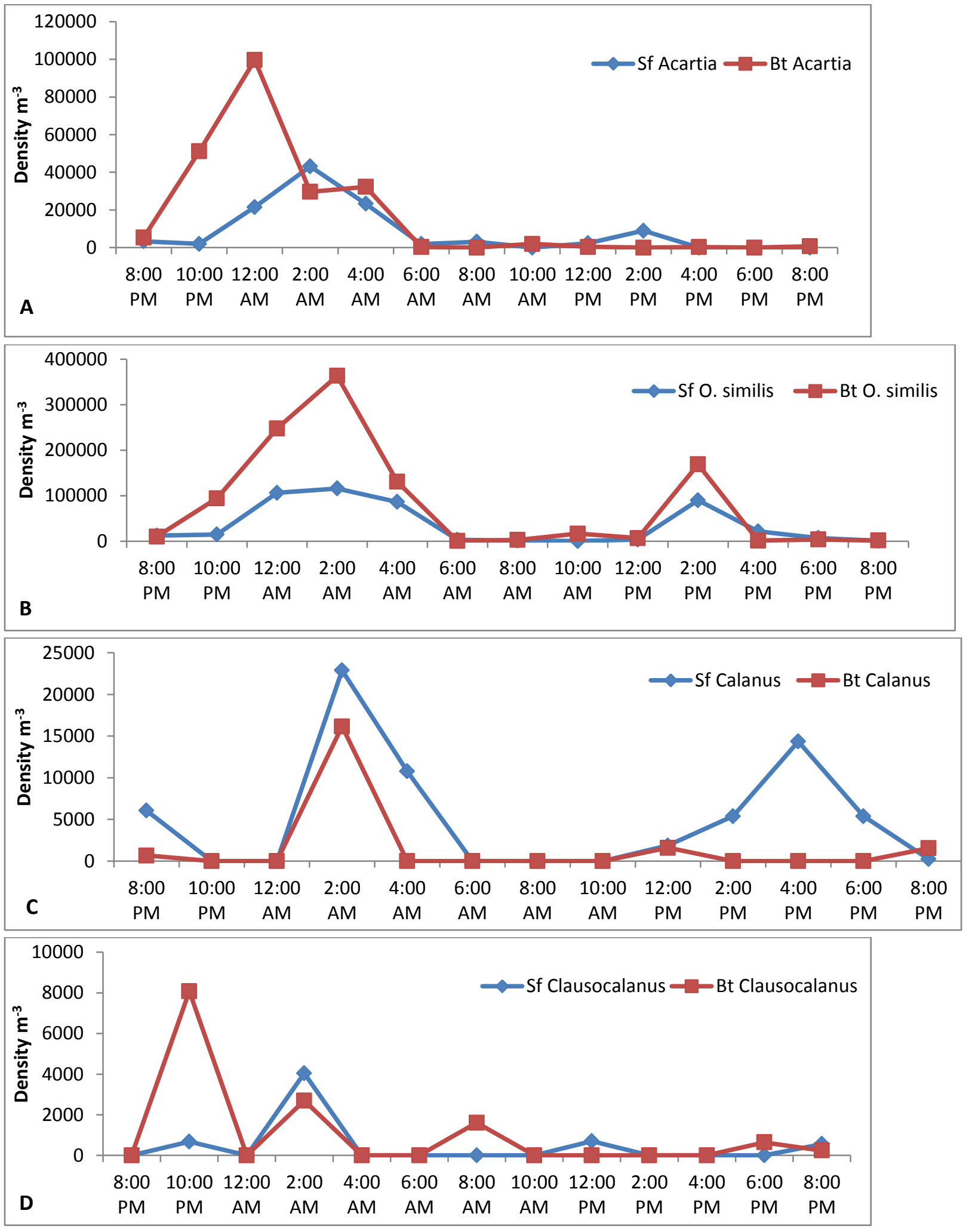
Figure 2. Copepod density vs. time at Ventura Point in July. Blue lines with diamonds indicate near-surface (Sf) densities. Red lines with squares indicate 0.5 $\mathrm{m}$ above bottom $(\mathrm{Bt})$ densities. A: Oithona similis, B: Calanus helgolandicus, C: Clausocalanus spp. 

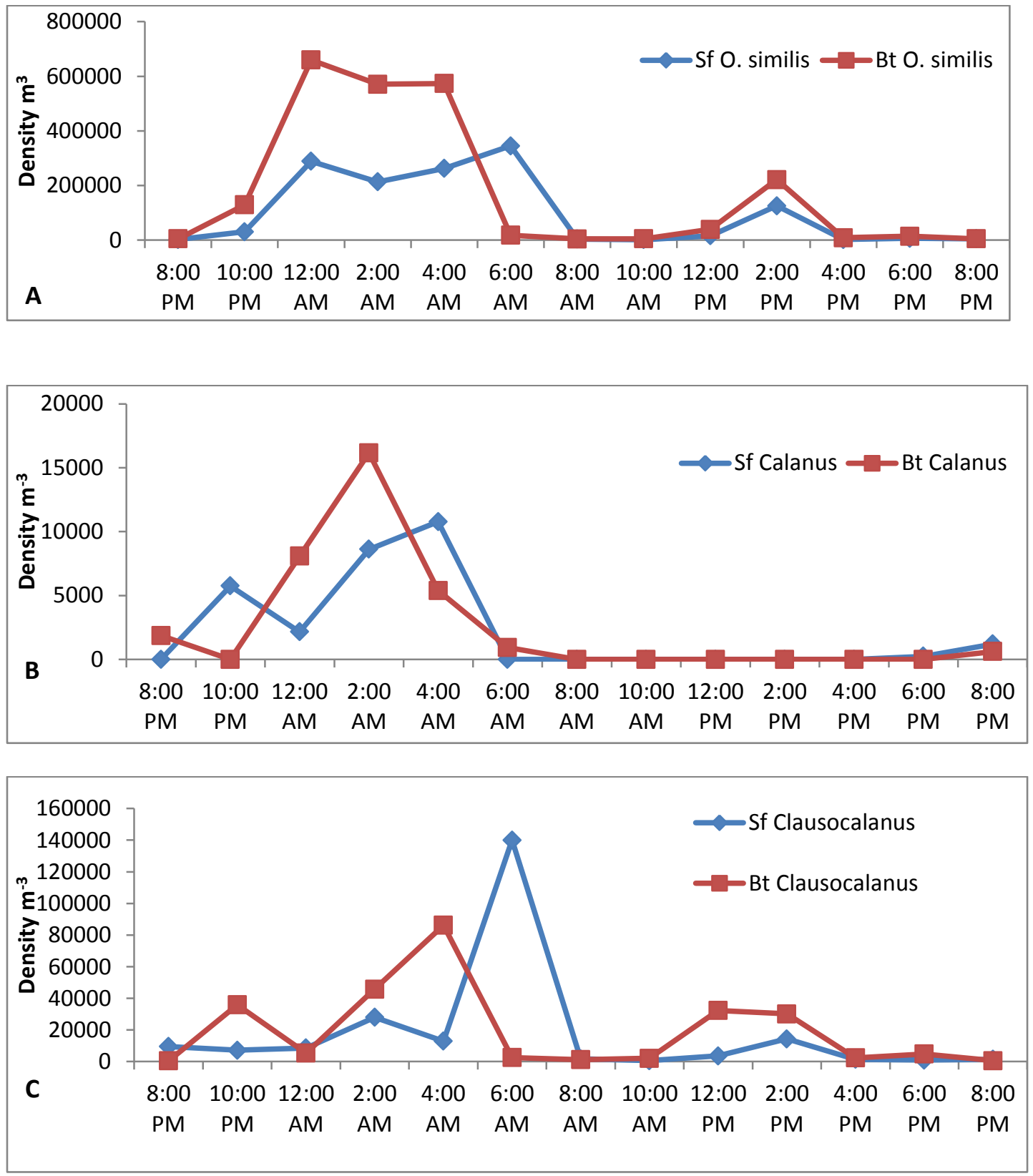
Figure 3. Copepod density vs. time at Ventura Point in July. Blue lines with diamonds indicate near-surface (Sf) densities. Red lines with squares indicate 0.5 $\mathrm{m}$ above bottom (Bt) densities. A: Acartia clausi and Acartia tonsa, B: Oithona similis, C: Calanus helgolandicus, D: Clausocalanus spp. 

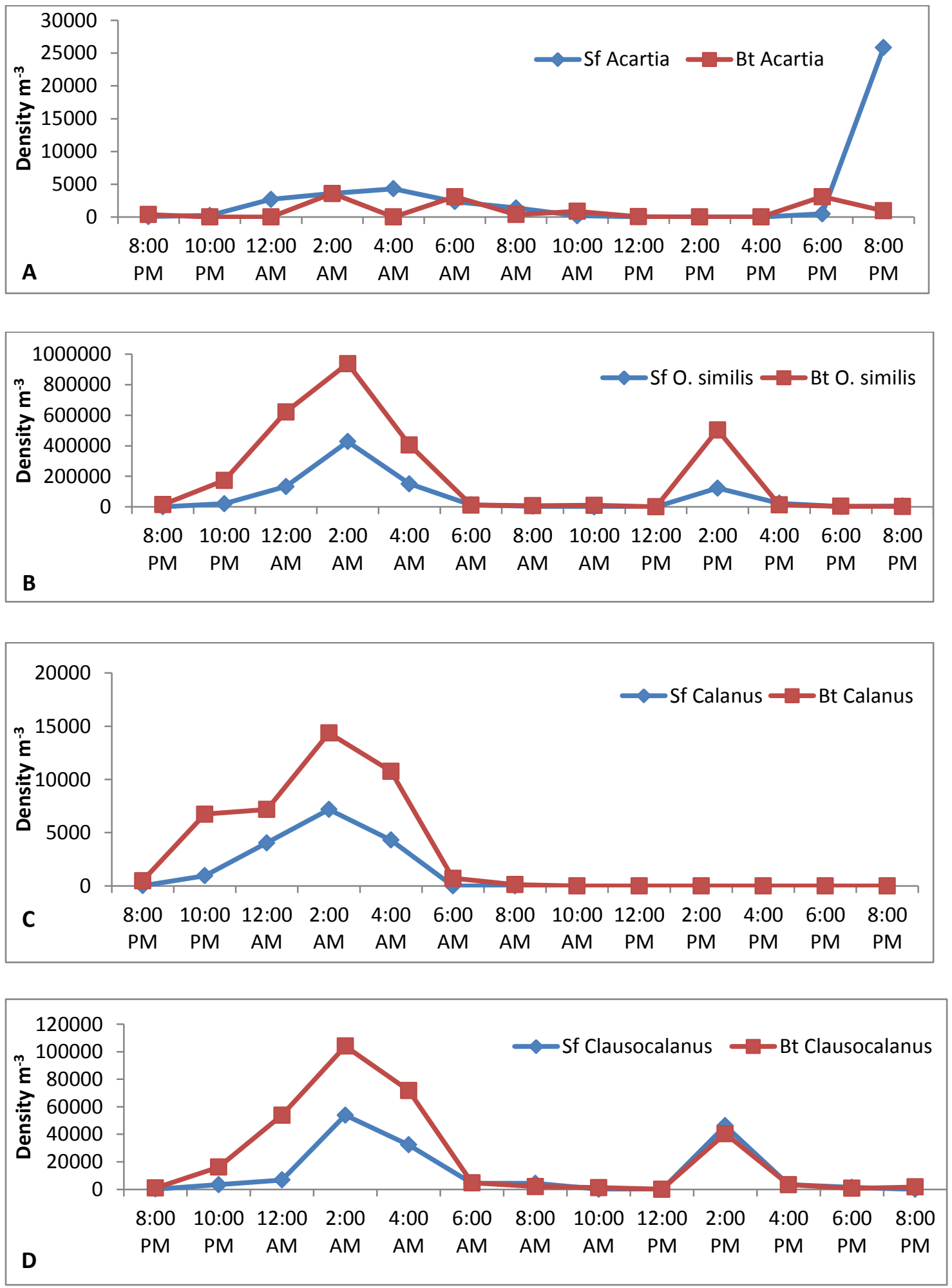
Figure 4. Copepod density vs. time at Ventura Point in July. Blue lines with diamonds indicate near-surface (Sf) densities. Red lines with squares indicate 0.5 $\mathrm{m}$ above bottom (Bt) densities. A: Acartia clausi and Acartia tonsa, B: Oithona similis, C: Calanus helgolandicus. 

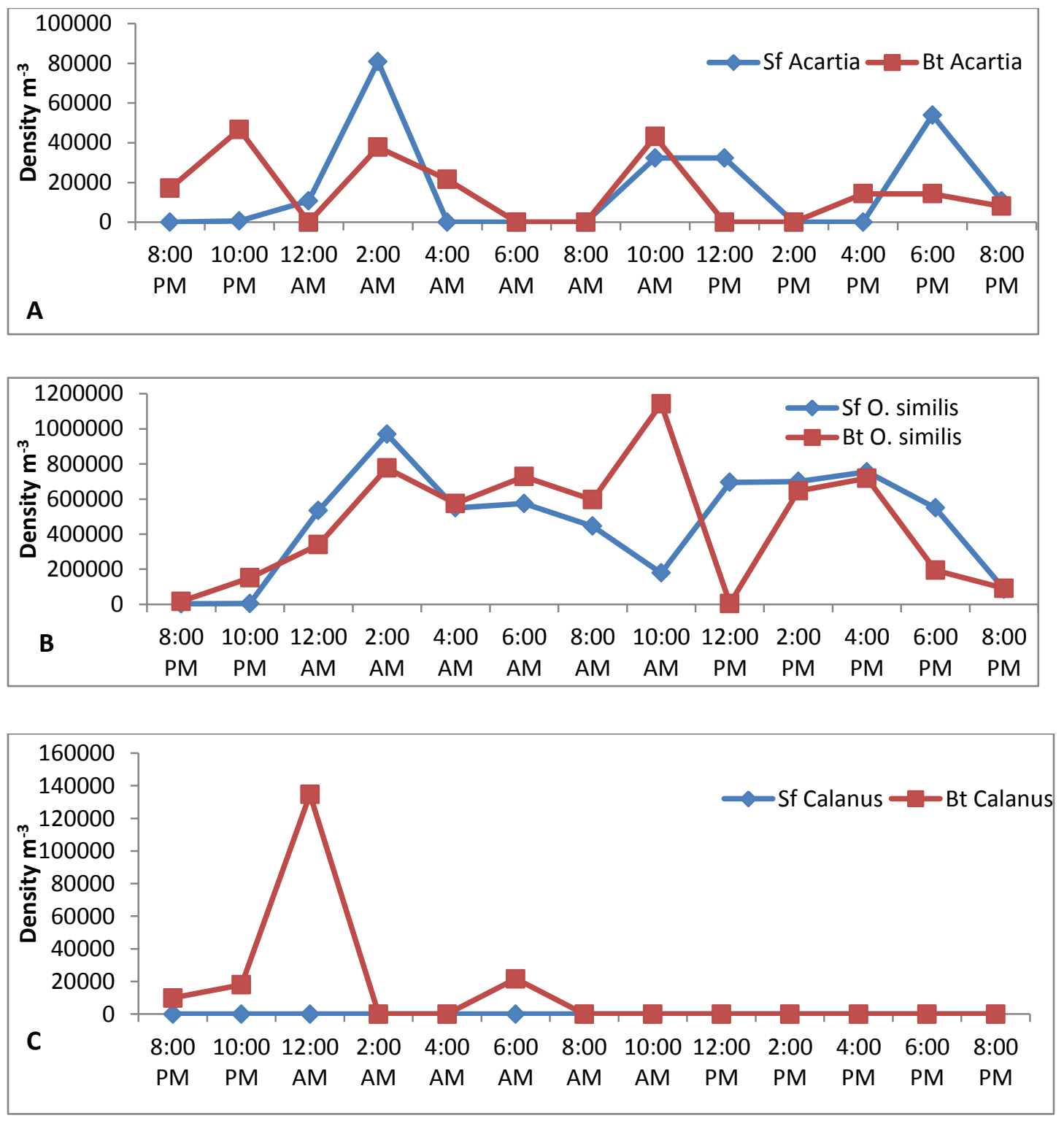
Figure 5. Copepod density vs. time at Ventura Point in July. Blue lines with diamonds indicate near-surface (Sf) densities. Red lines with squares indicate 0.5 $\mathrm{m}$ above bottom (Bt) densities. A: Oithona similis, B: Clausocalanus spp. 

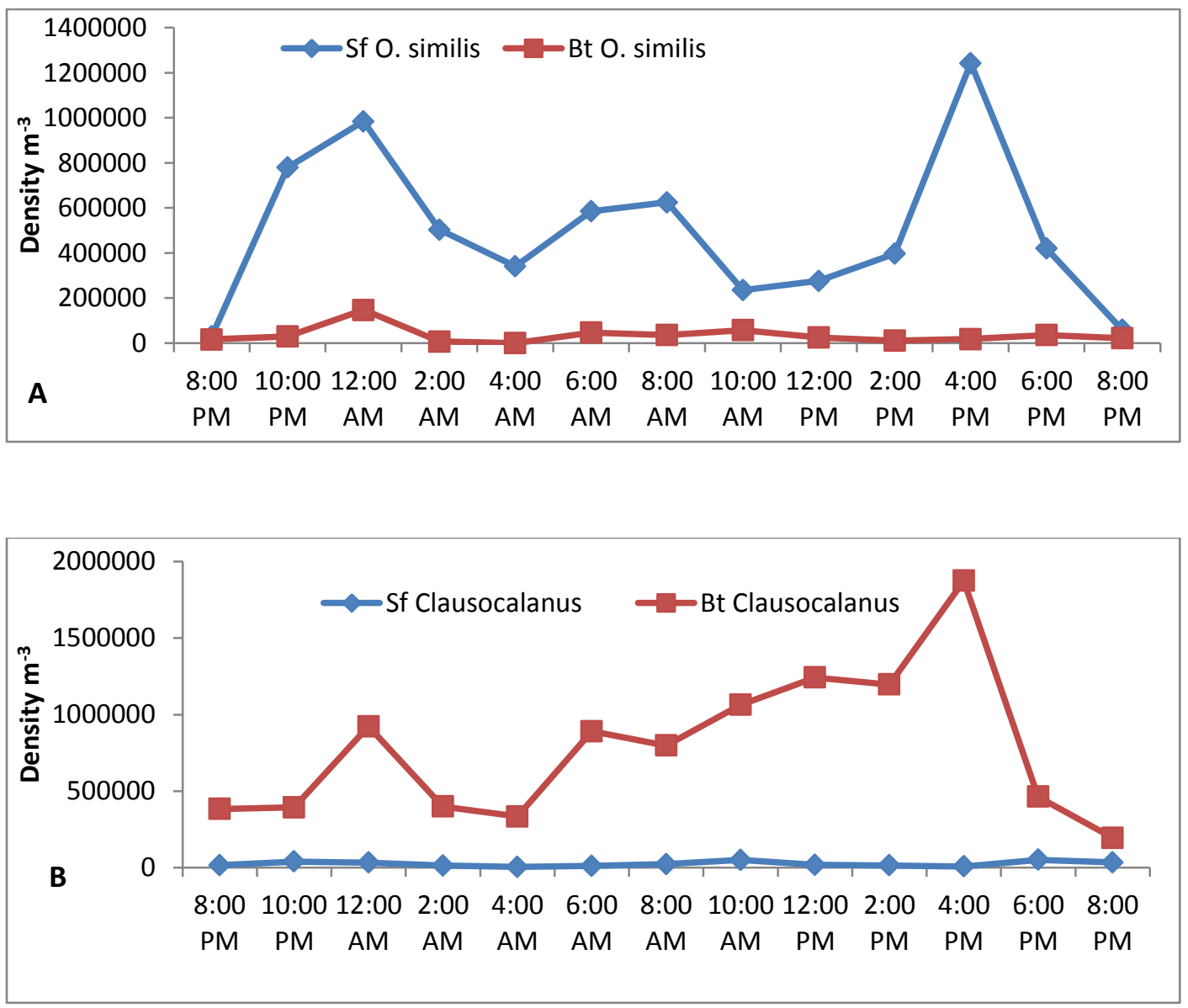
Figure 6. Copepod density vs. time at Ventura Point in July. Blue lines with diamonds indicate near-surface (Sf) densities. Red lines with squares indicate 0.5 m above bottom (Bt) densities. A: Oithona similis, B: Clausocalanus spp. 

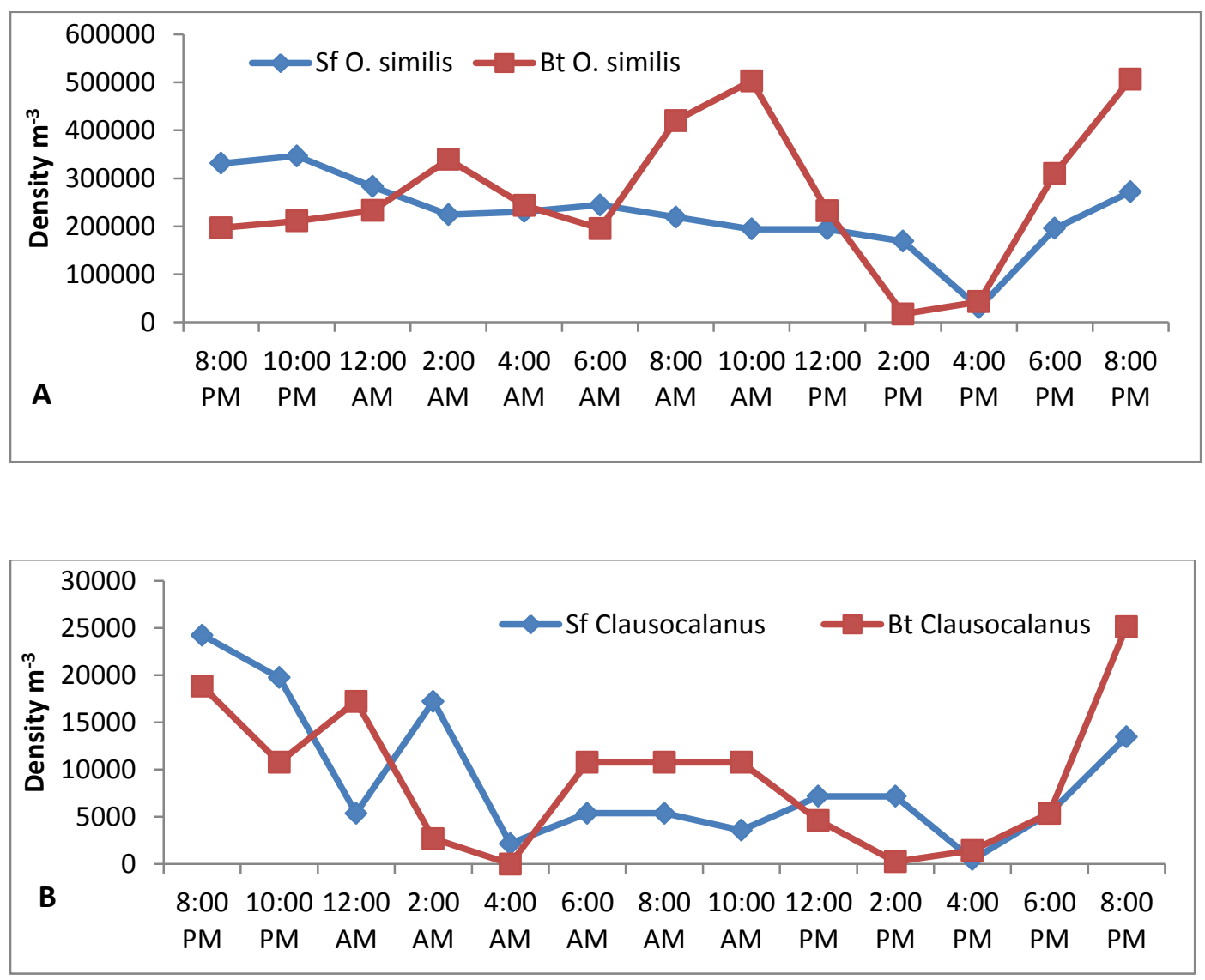
Figure 7. Copepod density vs. time at Ventura Point in July. Blue lines with diamonds indicate near-surface (Sf) densities. Red lines with squares indicate 0.5 $\mathrm{m}$ above bottom (Bt) densities. A: Acartia clausi and Acartia tonsa, B: Oithona similis, C: Calanus helgolandicus. 


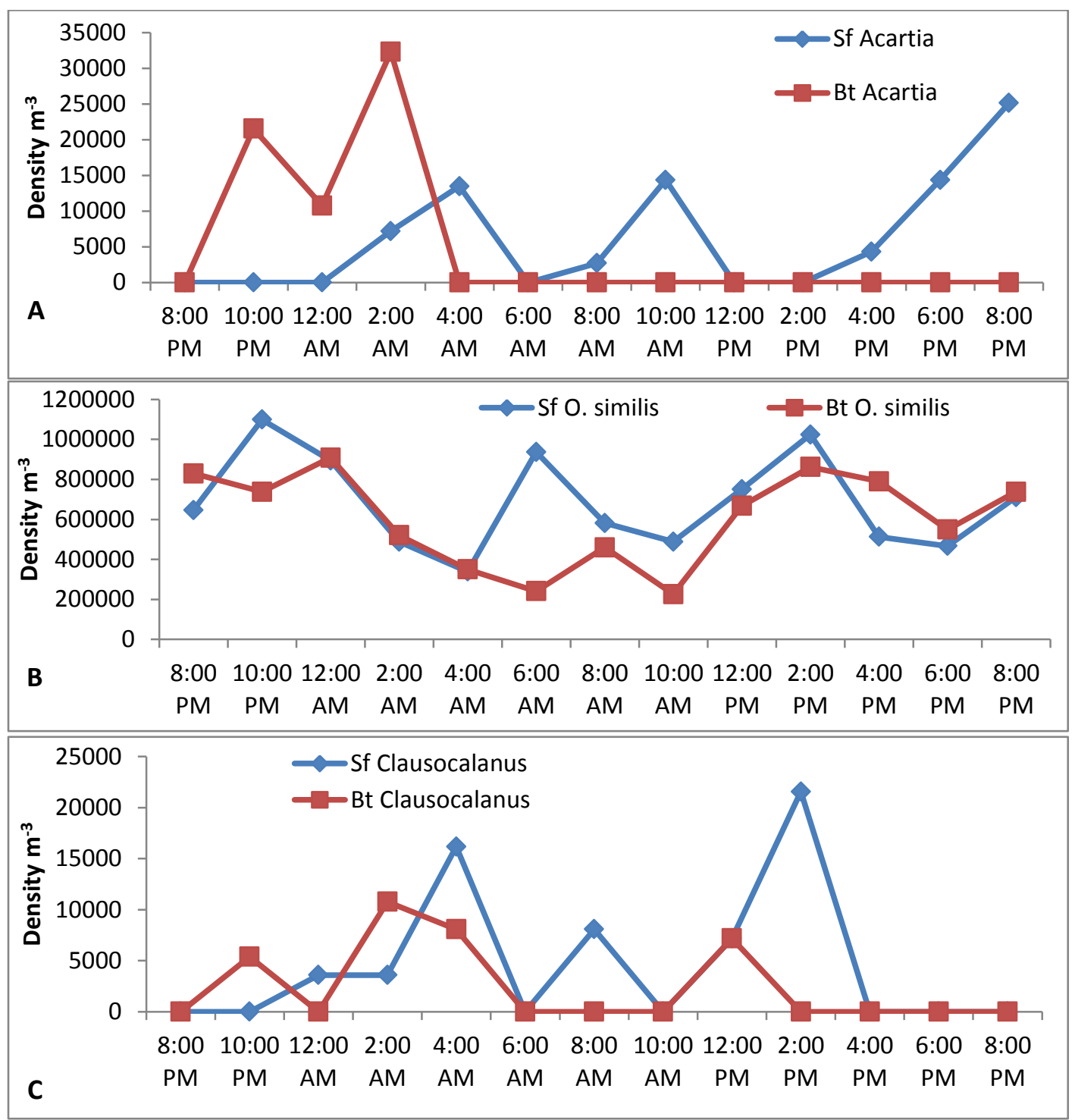


Figure 8. Copepod density vs. time at Ventura Point in July. Blue lines with diamonds indicate near-surface (Sf) densities. Red lines with squares indicate 0.5 $\mathrm{m}$ above bottom (Bt) densities. A: Oithona similis, B: Clausocalanus spp. 

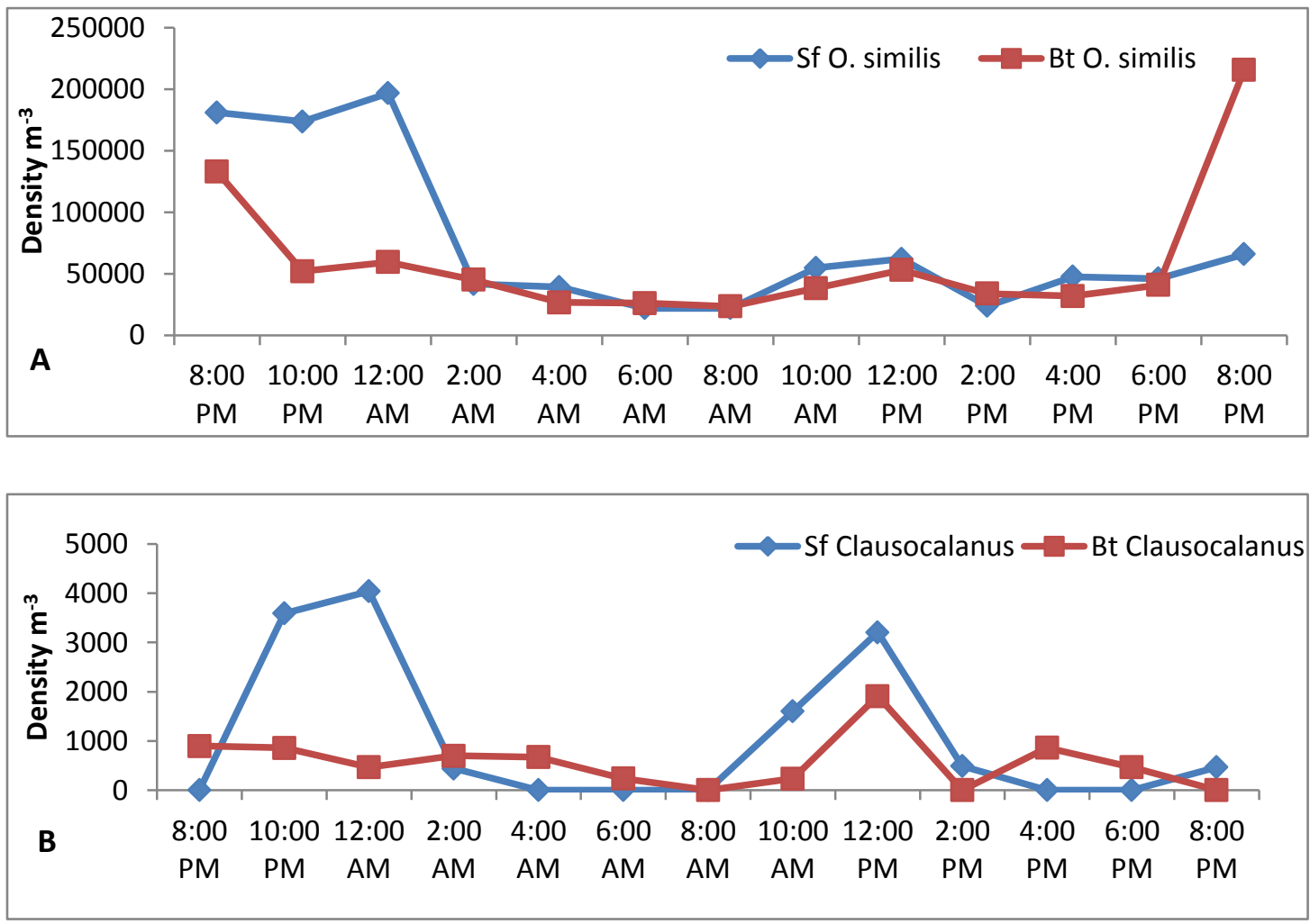
Figure 9. Copepod density vs. time at Ventura Point in July. Blue lines with diamonds indicate near-surface (Sf) densities. Red lines with squares indicate 0.5 $\mathrm{m}$ above bottom (Bt) densities. A: Oithona similis, B: Clausocalanus spp. 

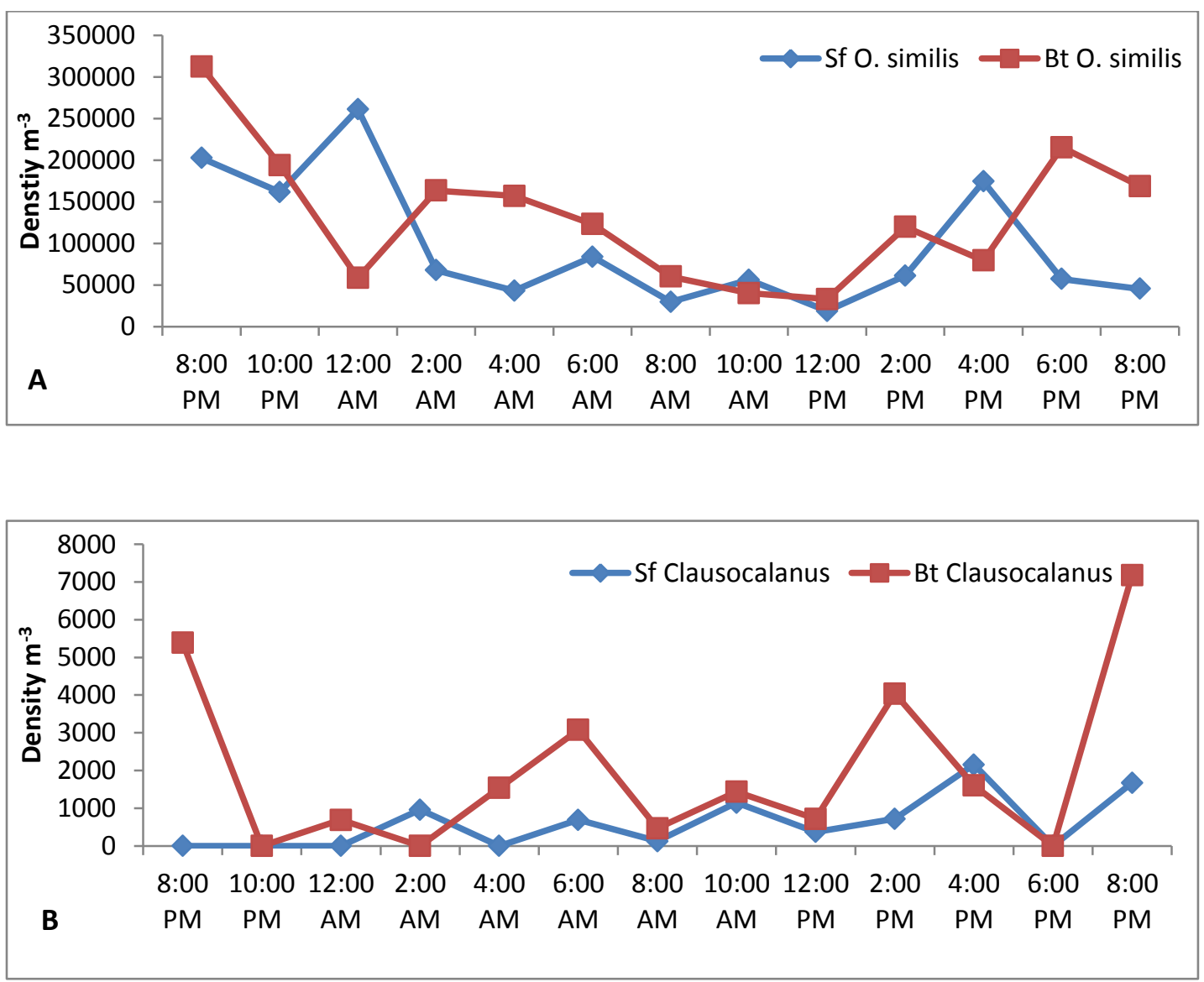
Figure 10. Temperature, salinity, chlorophyll $a$, and dissolved oxygen depth profiles at each of the three study sites over the three month period from July to September 2016. Solid lines indicate high tide. Dashed lines indicate low tide. Solid arrows indicate sunrise. Dashed arrows indicate sunset. In most cases when depth profiles could not be measured, panels with missing data show measurements from water samples collected near the surface and $0.5 \mathrm{~m}$ above bottom 


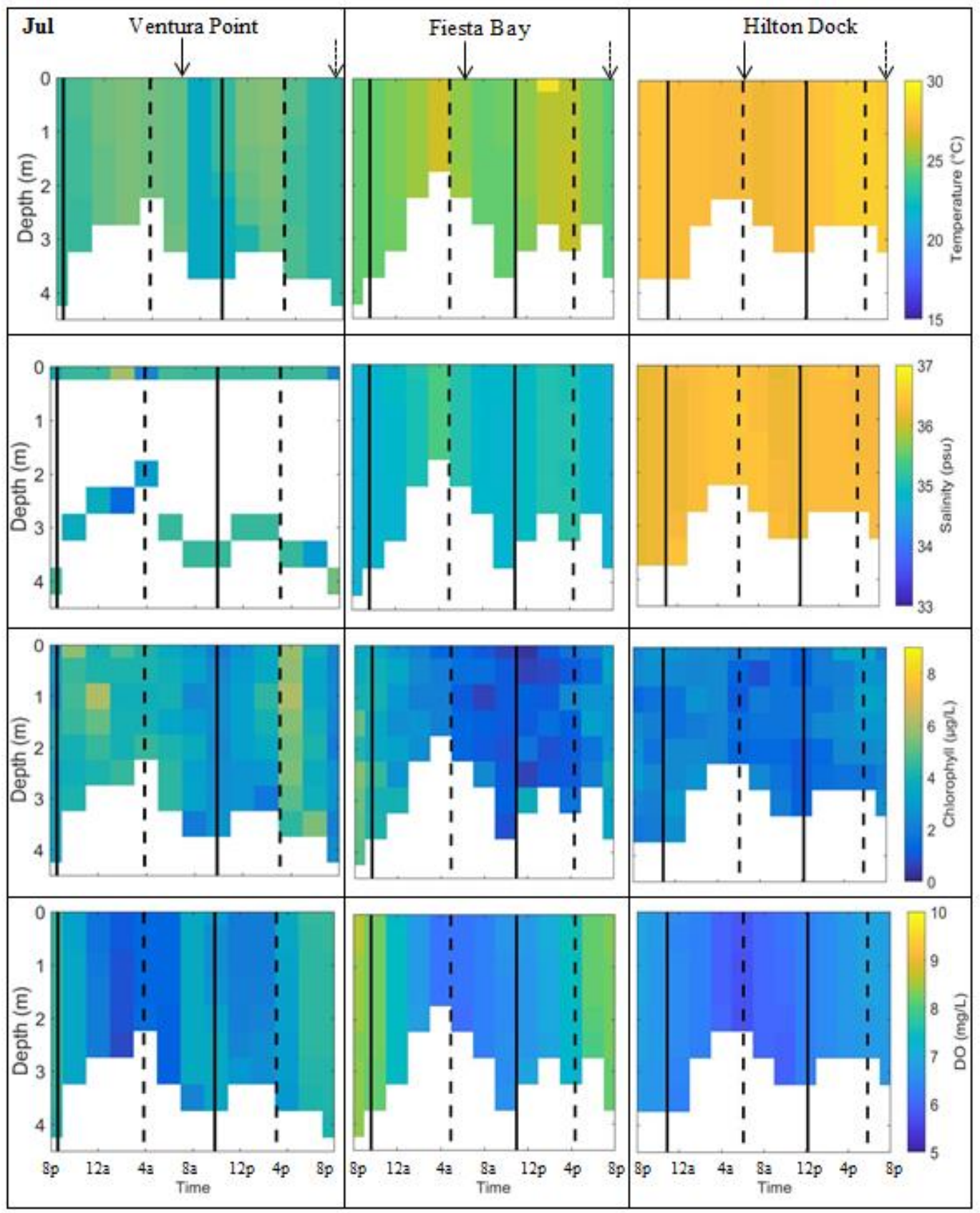




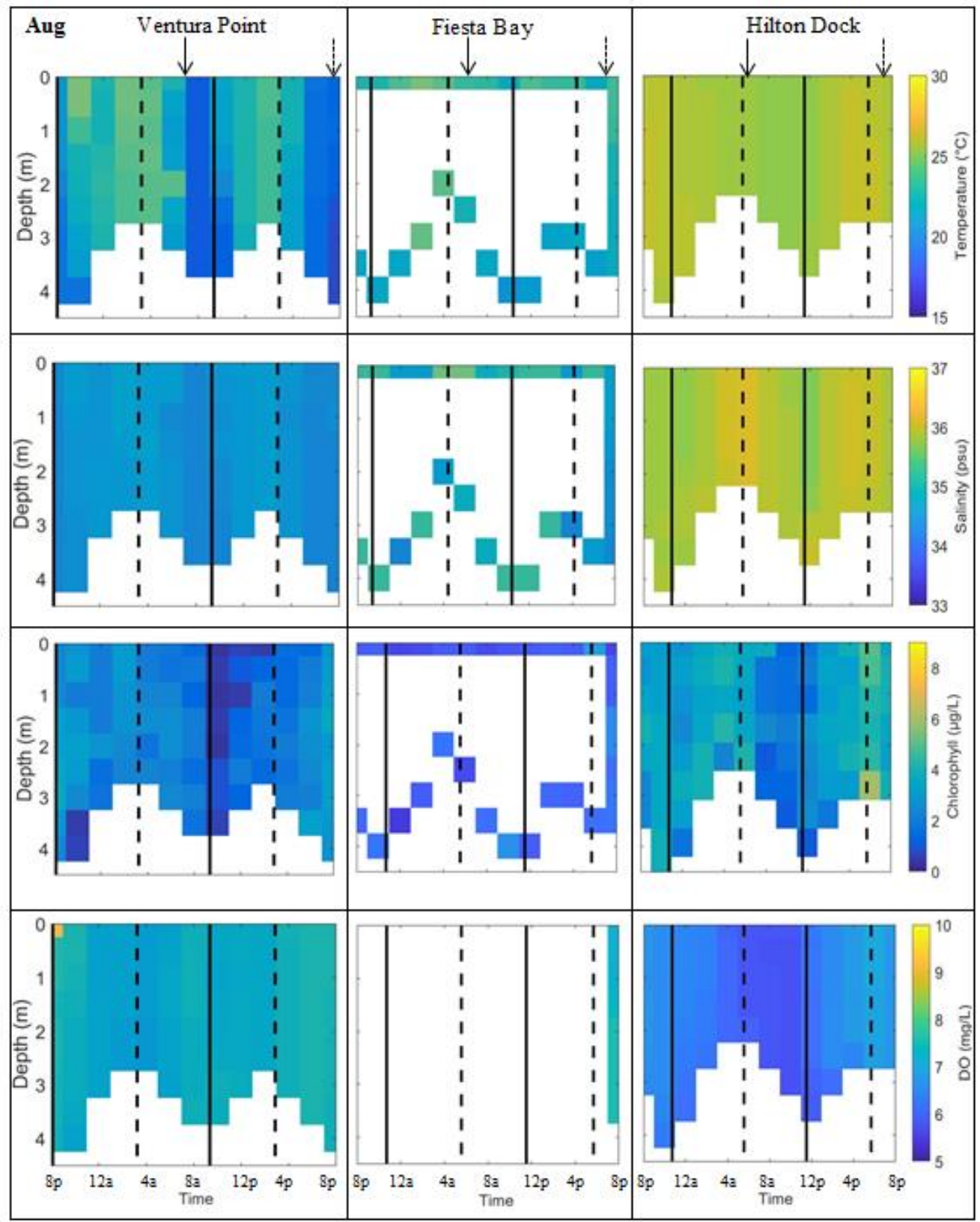




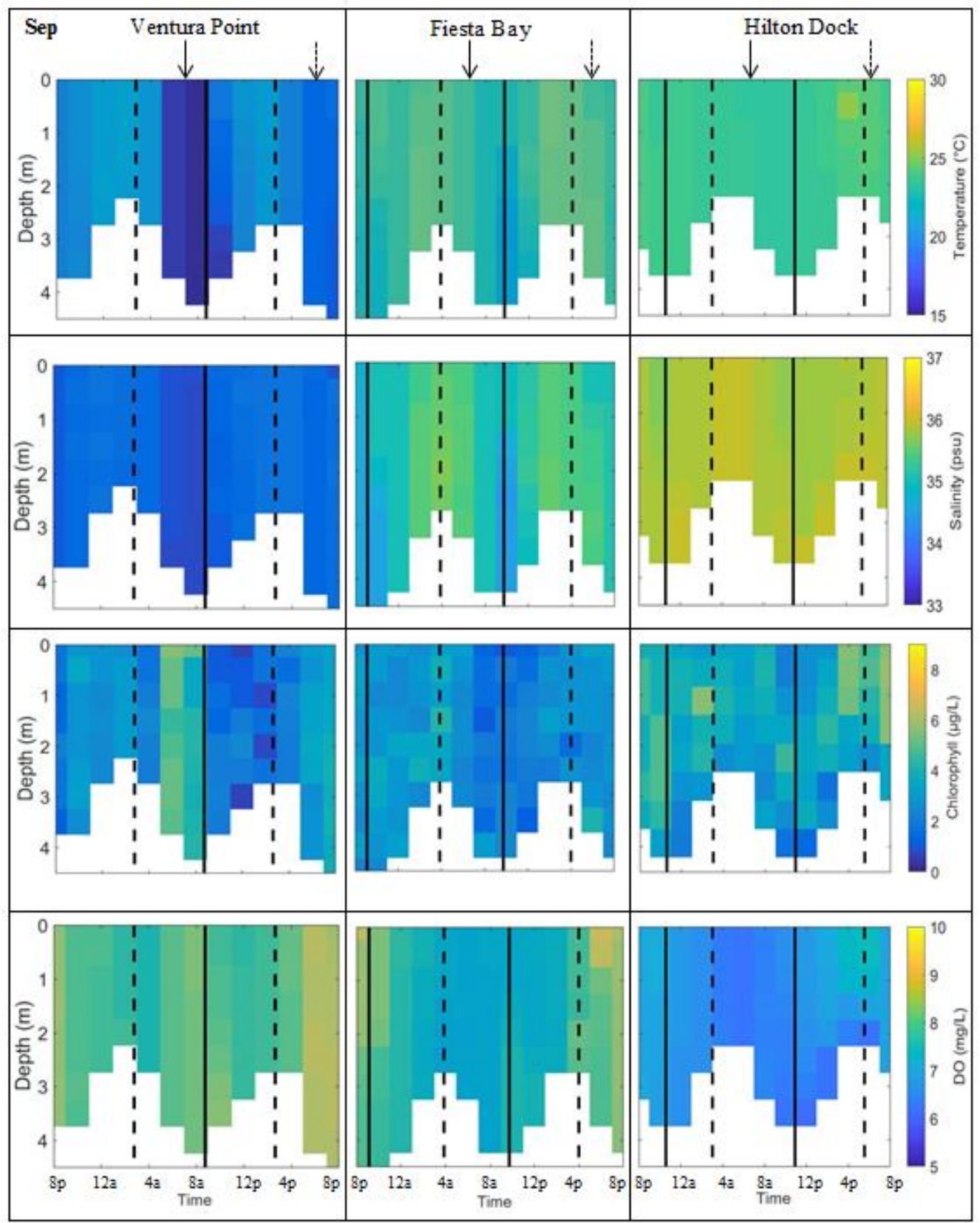


Figure 11. Chlorophyll $a$ and phaeopigment concentrations at the surface and 0.5 $\mathrm{m}$ above bottom over 24 hour sampling periods during July - September 2016 at each site: Ventura Point (VP), Fiesta Bay (FB), and Hilton Dock (HD). Shaded boxes represent nighttime. Solid arrows indicate high tide, dashed arrows indicate low tide. 


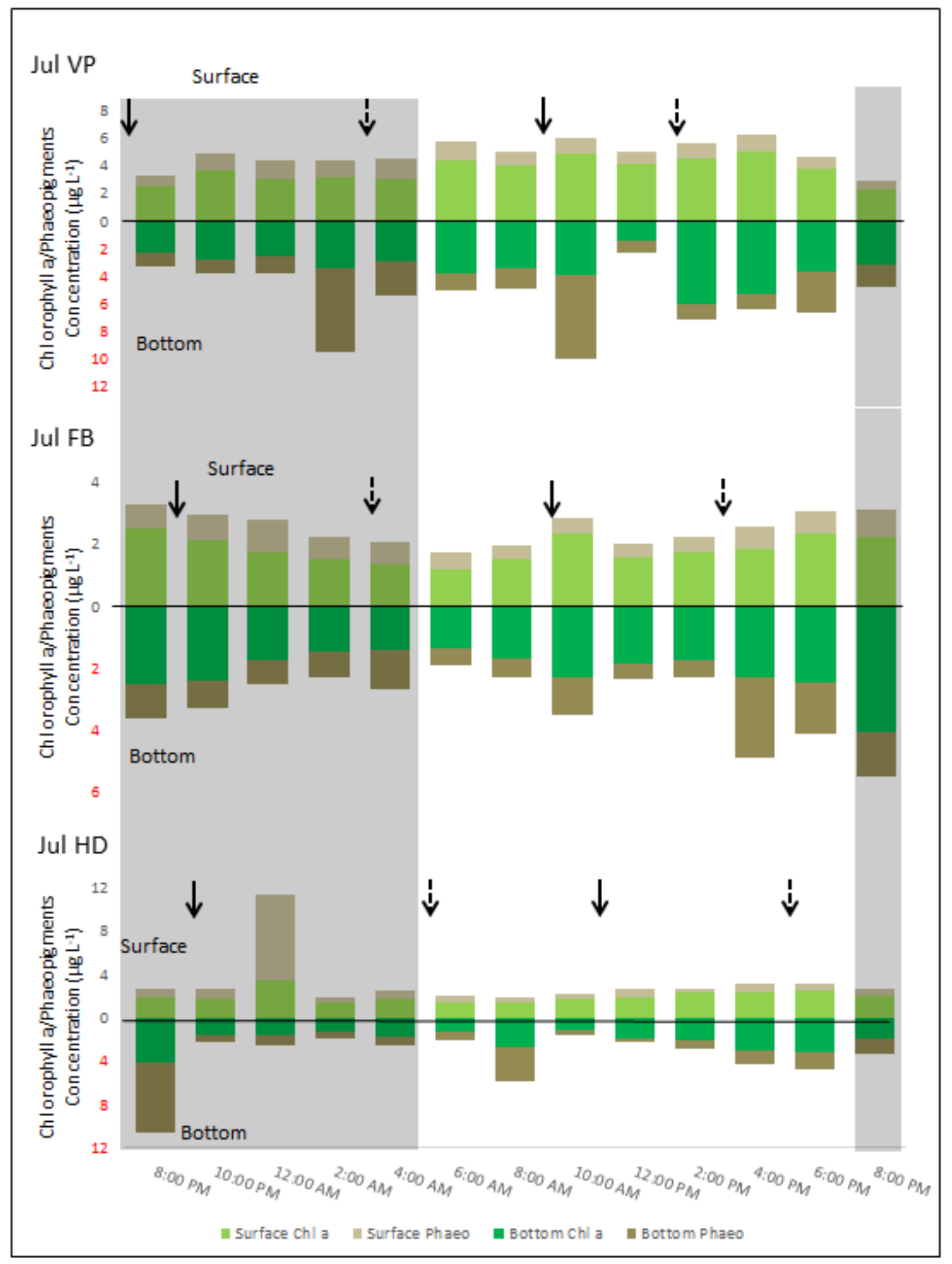




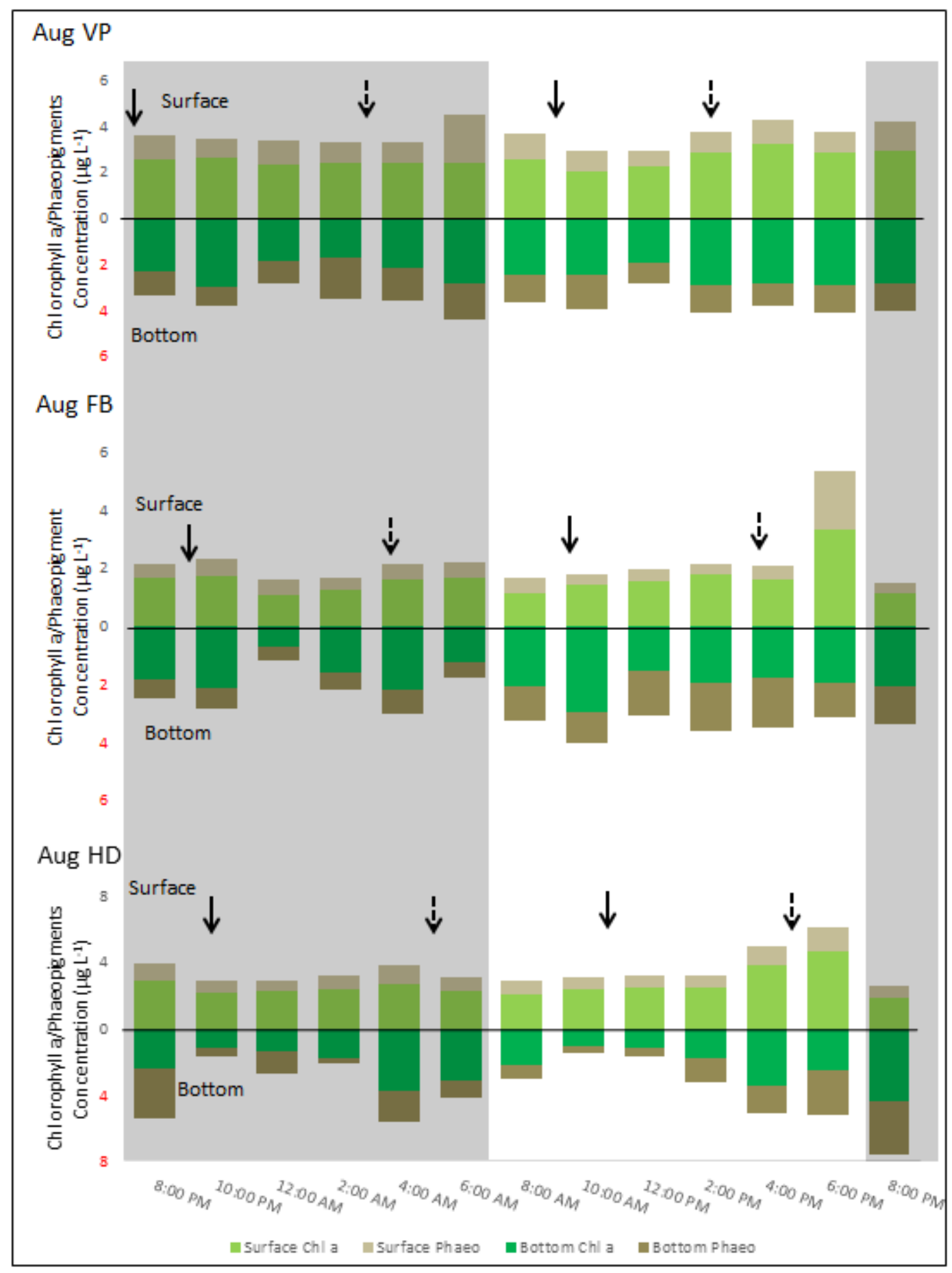




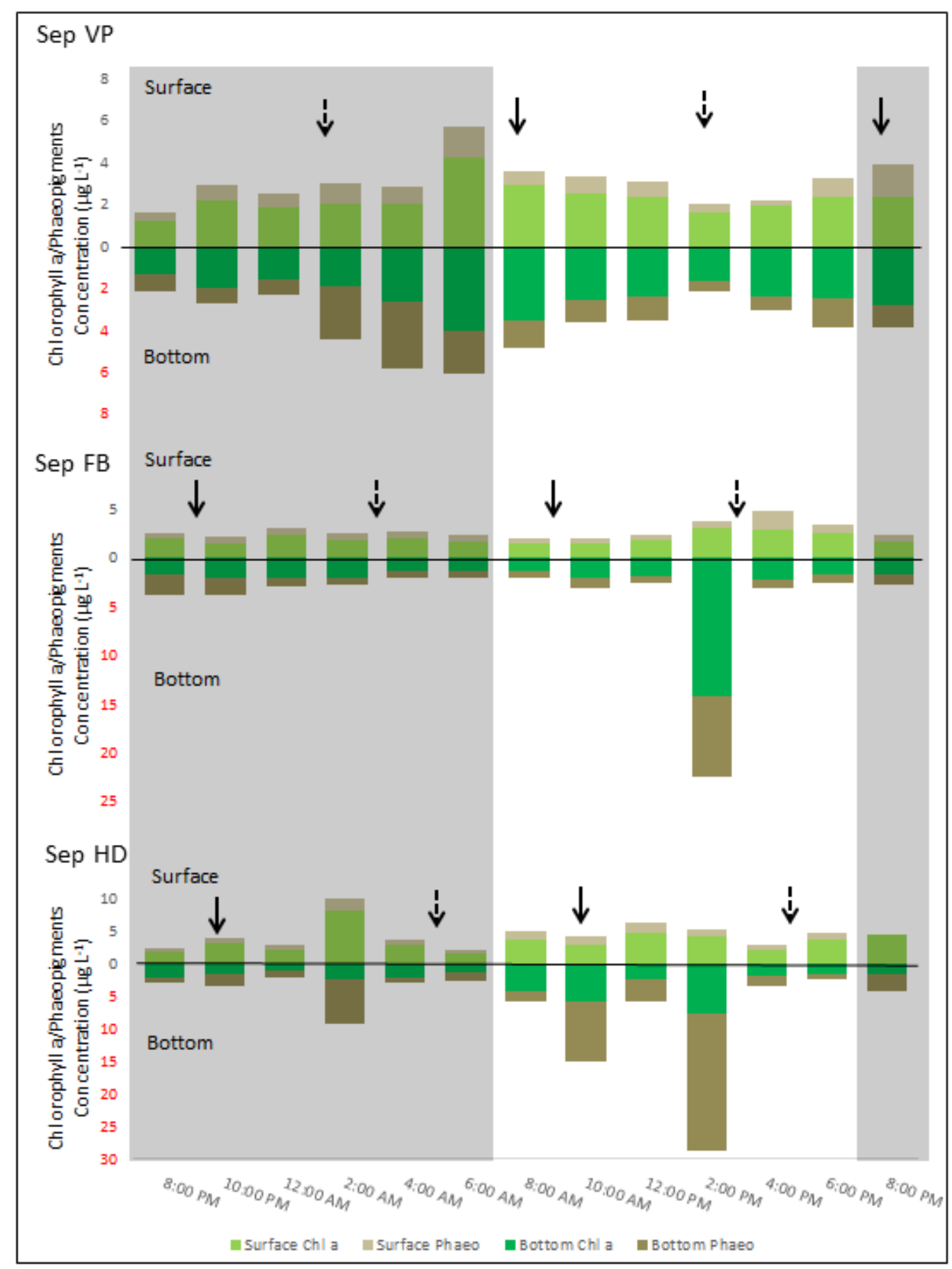


Table 1. Complete list of taxa observed in this study. 


\begin{tabular}{|ll|}
\hline Copepods & Acartia clausi \\
& Acartia tonsa \\
& Calanus helgolandicus \\
& Clausocalanus spp. \\
& Corycaeus giesbrechti \\
& Euterpina acutifrons \\
& Juvenile copepods \\
& Oithona nana \\
& Oithona oculata \\
& Oithona setigera \\
& Oithona similis \\
& Oncaea sp. \\
& Barnacle nauplius \\
& Bivalve veliger \\
Bryozoan larva \\
Chrysopetalidae \\
Crab zoea \\
Gastropod veliger \\
Longepedia sp. \\
Nauplius 1-2 \\
Nauplius 3-4 \\
Nauplius 5-6 \\
Phyllodoridae \\
Polychaete larva \\
Worm planula \\
Codonellopsis bulbulus \\
Parafavella sp. \\
Tintinnopsis campanula \\
Tintinnopsis cylindrica \\
Amphipod \\
Cladoceran \\
Foraminiferan \\
Jellyfish MOQ \\
Mysid \\
Oikopleura sp. \\
Polychaete \\
\\
\end{tabular}


Figure 12. Copepod densities $\left(\times 10^{6} \mathrm{~m}^{-3}\right)$ for each site just below the surface and $0.5 \mathrm{~m}$ above bottom over 24-hour sampling periods. Solid arrows indicate high tide, dashed arrows indicate low tide. Blue is Ventura Point, red is Fiesta Bay, and green is Hilton Dock. 


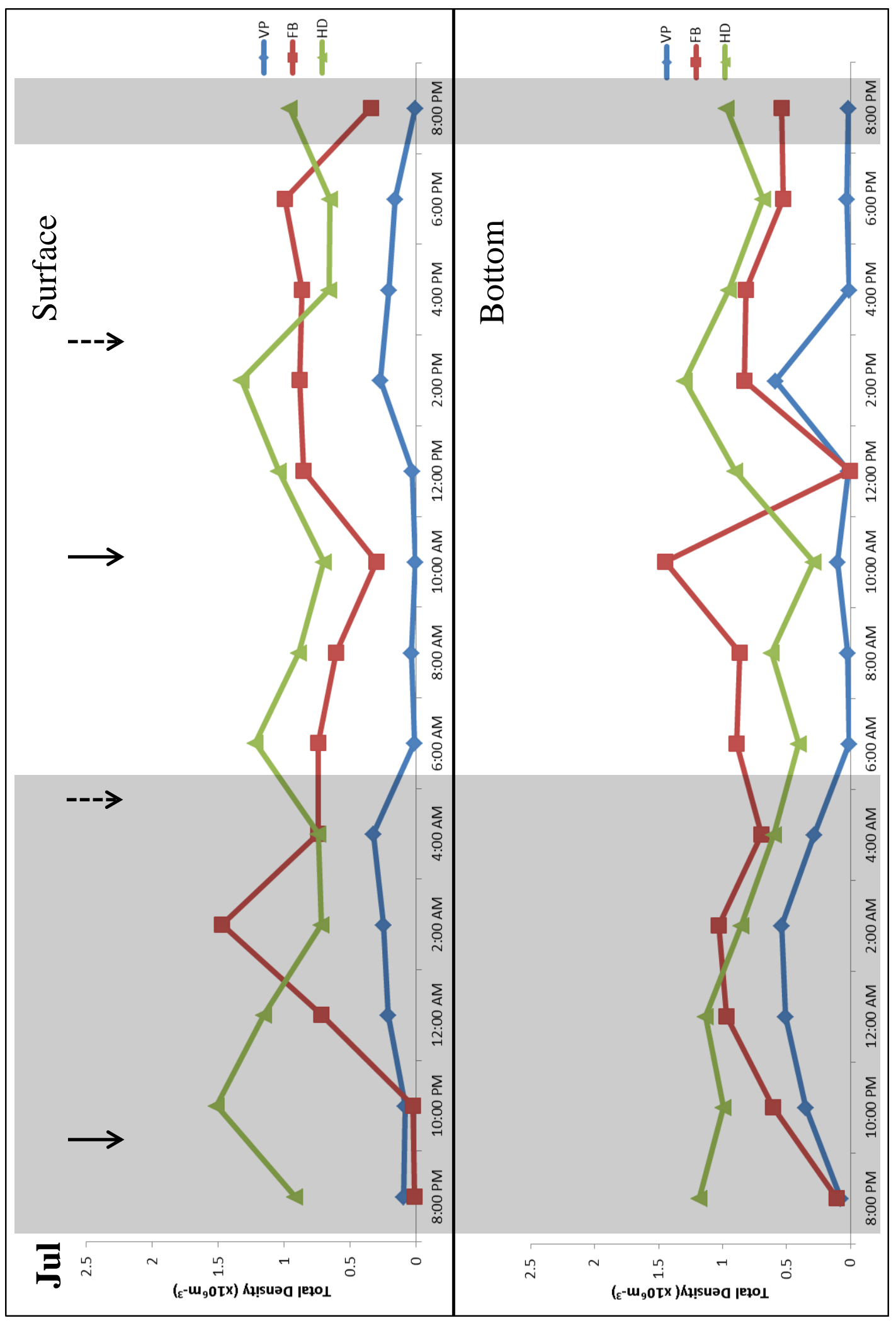




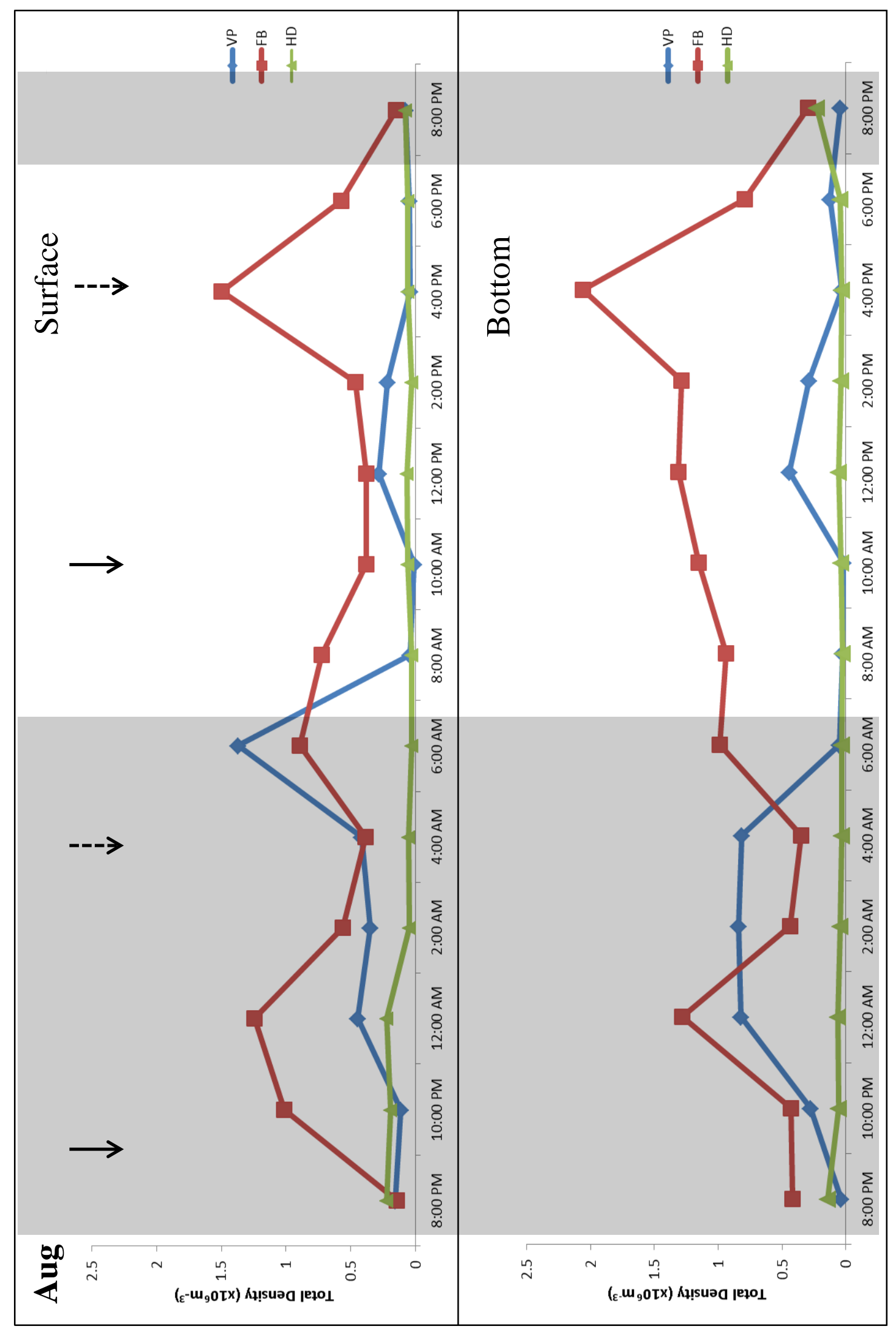




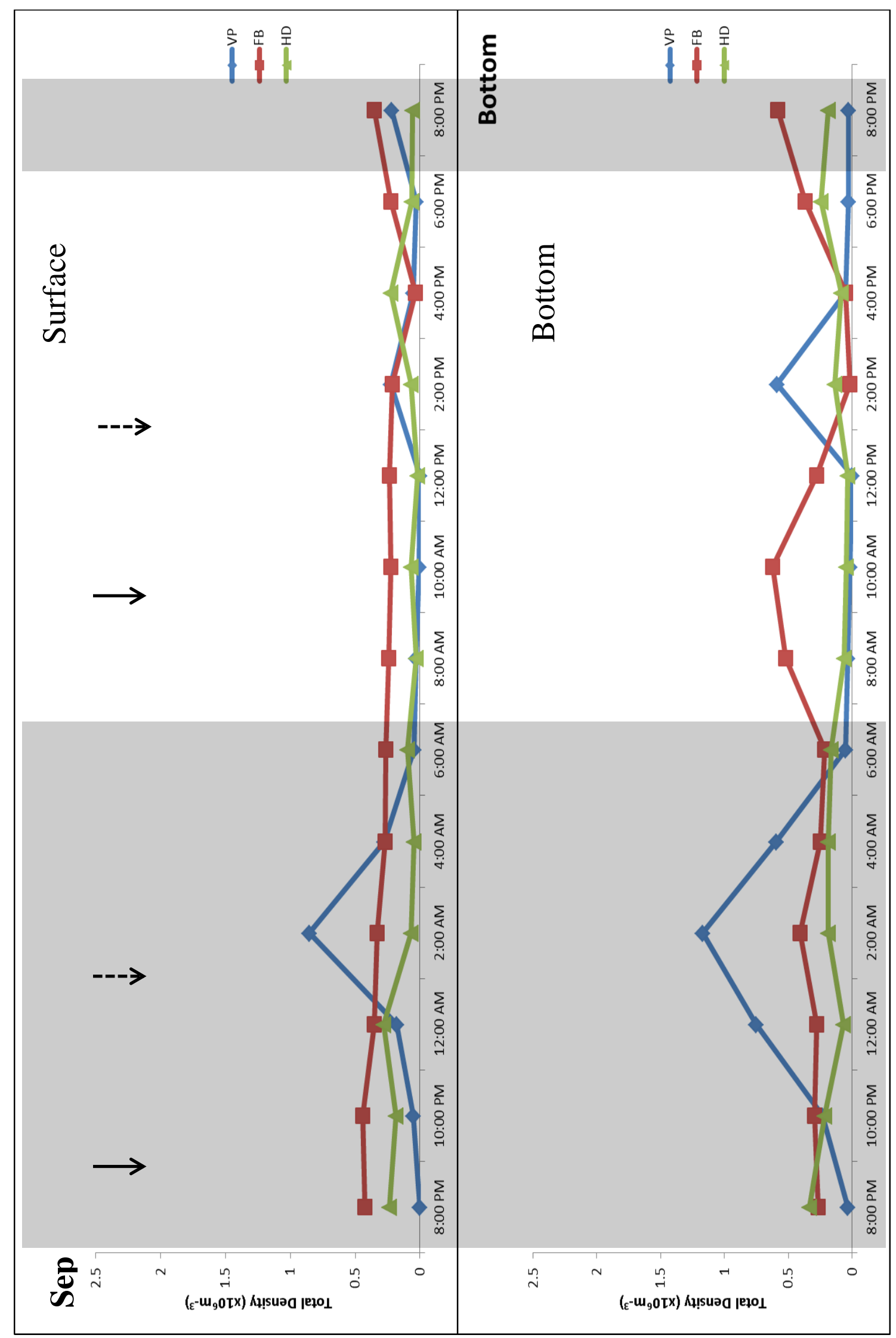

